\title{
Chemical ozone losses in Arctic and Antarctic polar winter/spring season derived from SCIAMACHY limb measurements 2002-2009
}

\author{
T. Sonkaew ${ }^{1,2}$, C. von Savigny ${ }^{1, *}$, K.-U. Eichmann ${ }^{1}$, M. Weber ${ }^{1}$, A. Rozanov $^{1}$, H. Bovensmann ${ }^{1}$, J. P. Burrows ${ }^{1}$, and \\ J.-U. Grooß ${ }^{3}$ \\ ${ }^{1}$ Institute of Environmental Physics, University of Bremen, Otto-Hahn-Allee 1, 28359 Bremen, Germany \\ ${ }^{2}$ Science Faculty, Lampang Rajabhat University, 119 Lampang-Maeta Rd., Lampang, 52100, Thailand \\ ${ }^{3}$ Institute for Energy and Climate Research - Stratosphere (IEK-7), Forschungszentrum Jülich, Jülich, Germany \\ *now at: Institute of Physics, Ernst-Moritz-Arndt-University of Greifswald, Felix-Hausdorff-Str. 6, \\ 17489 Greifswald, Germany
}

Correspondence to: T. Sonkaew (thiranan@lpru.ac.th)

Received: 24 January 2011 - Published in Atmos. Chem. Phys. Discuss.: 23 February 2011

Revised: 13 January 2013 - Accepted: 22 January 2013 - Published: 19 February 2013

\begin{abstract}
Stratospheric ozone profiles are retrieved for the period 2002-2009 from SCIAMACHY measurements of limb-scattered solar radiation in the Hartley and Chappuis absorption bands of ozone. This data set is used to determine the chemical ozone losses in both the Arctic and Antarctic polar vortices by averaging the ozone in the vortex at a given potential temperature. The chemical ozone losses at isentropic levels between $450 \mathrm{~K}$ and $600 \mathrm{~K}$ are derived from the difference between observed ozone abundances and the ozone modelled taking diabatic cooling into account, but no chemical ozone loss. Chemical ozone losses of up to 30$40 \%$ between mid-January and the end of March inside the Arctic polar vortex are reported. Strong inter-annual variability of the Arctic ozone loss is observed, with the cold winters 2004/2005 and 2006/2007 showing chemical ozone losses inside the polar vortex at $475 \mathrm{~K}$, where $1.7 \mathrm{ppmv}$ and $1.4 \mathrm{ppmv}$ of ozone were removed, respectively, over the period from 22 January to beginning of April and 0.9 ppmv and 1.2 ppmv, respectively, during February. For the winters of $2007 / 2008$ and 2002/2003, ozone losses of about $0.8 \mathrm{ppmv}$ and $0.4 \mathrm{ppmv}$, respectively are estimated at the $475 \mathrm{~K}$ isentropic level for the period from 22 January to beginning of April. Essentially no ozone losses were diagnosed for the relatively warm winters of 2003/2004 and 2005/2006. The maximum ozone loss in the SCIAMACHY data set was found in 2007 at the $600 \mathrm{~K}$ level and amounted to about $2.1 \mathrm{ppmv}$ for the period between 22 January and the end of April. Enhanced losses close to this altitude were found in all inves-
\end{abstract}

tigated Arctic springs, in contrast to Antarctic spring. The inter-annual variability of ozone losses and PSC occurrence rates observed during Arctic spring is consistent with the known QBO effects on the Arctic polar vortex, with exception of the unusual Arctic winter 2008/2009.

The maximum total ozone mass loss of about 25 million tons was found in the cold Arctic winter of 2004/2005 inside the polar vortex between the $450 \mathrm{~K}$ and $600 \mathrm{~K}$ isentropic levels from mid-January until the middle of March.

The Antarctic vortex averaged ozone loss as well as the size of the polar vortex do not vary much from year to year. The total ozone mass loss inside the Antarctic polar vortex between the $450 \mathrm{~K}$ and $600 \mathrm{~K}$ isentropic levels is about 50 60 million tons and the vortex volume for this altitude range varies between about 150 and $300 \mathrm{~km}^{3}$ for the period between mid-August and mid-November of every year studied, except for 2002. In 2002 a mid-winter major stratospheric warming occurred in the second half of September and the ozone mass loss was only about half of the value in the other years. However, inside the polar vortex we find chemical ozone losses at the $475 \mathrm{~K}$ isentropic level that are similar to those in all other years studied. At this isentropic level ozone losses of 70-90\% between mid-August and mid-November or about $2.5 \mathrm{ppmv}$ are observed every year. At isentropic levels above $500 \mathrm{~K}$ the chemical ozone losses were found to be larger in 2002 than in all other years studied.

Comparisons of the vertical variation of ozone losses derived from SCIAMACHY observations with several 
independent techniques for the Arctic winter 2004/2005 show that the SCIAMACHY results fall in the middle of the range of previously published results for this winter. For other winters in both hemispheres - for which comparisons with other studies were possible - the SCIAMACHY results are consistent with the range of previously published results.

\section{Introduction}

Stratospheric ozone is of great importance, because it protects life on Earth from harmful ultraviolet solar radiation. As a result of the anthropogenic release of halogen compounds, stratospheric ozone has been decreasing globally during the second half of the 20th century up to the mid-nineties, when a change of the sign of the ozone trend occurred, particularly in the upper stratospheric region (e.g., Newchurch et al., 2003; Jones et al., 2009; Steinbrecht et al., 2009). The threat resulting from the uncontrolled release of ozone depleting substances was dramatically emphasized with the discovery of the Antarctic ozone hole by Farman et al. (1985). The Antarctic ozone hole is usually associated with the neartotal catalytic destruction of ozone in the polar vortex at isentropic levels between about $400 \mathrm{~K}$ and $500 \mathrm{~K}$ (about 15$20 \mathrm{~km}$ altitude) (e.g., Hoppel et al., 2003; Solomon et al., 2005, 2007), but ozone losses are also observed down to the $350 \mathrm{~K}$ isentropic level (e.g., Tilmes et al., 2006). Substantial ozone losses in the Arctic polar vortex are also possible during cold winters.

In general, these ozone losses in the polar vortices are now understood to result from a complex physico-chemical mechanism, including chlorine activation by heterogeneous chemistry involving polar stratospheric clouds (PSCs) followed by catalytic ozone destruction (e.g., Solomon, 1999). However, the effects of some specific reactions remain unclear and need to be further investigated as polar ozone losses determined with different climate-chemistry models show significant differences as discussed in Chapter 6 of SPARC CCMVal (2010) and references therein. Several studies quantified the chemical ozone loss in the Arctic polar vortex using a variety of techniques and instruments (e.g., Chipperfield et al., 1996; Goutail et al., 1997; Deniel et al., 1998; Rex et al., 1999; Becker et al., 2000; Guirlet et al., 2000; Eichmann et al., 2002; Grooß and Müller, 2003; Goutail et al., 2005; El Amraoui et al., 2008). The methods employed to quantify the chemical ozone loss include, e.g., (1) the match technique (e.g. Rex et al., 2006), (2) tracer correlation (e.g. Tilmes et al., 2004), (3) passive subtraction (e.g. Singleton et al., 2007), (4) vortex average descent techniques (e.g. Eichmann et al., 2002), (5) Lagrangian transport calculations (e.g. Grooß and Müller, 2007), and (6) chemical data assimilation (e.g., Tsvetkova et al., 2007). Each method is based on different assumptions and is associated with different strengths and weaknesses (more details are provided in WMO (2007)). The results of different techniques to determine chemical ozone losses in the polar vortices have been compared by, e.g., Harris et al. (2002), Singleton et al. (2005), Kuttippurath et al. (2010a), and in WMO (2007). In general, reasonable agreement has been found.

This study deals with the determination of polar chemical ozone loss employing a vortex average method (e.g., Knudsen et al., 1998; EU, 2001; Eichmann et al., 2002; Kuttippurath et al., 2010a). The chemical ozone loss at a given isentropic surface is determined from the observed vortexaveraged ozone abundances taking the vertical transport of ozone into and out of this surface into account. A vortex average method is applied to determine polar chemical ozone losses between 2002 and 2009 in the Arctic and Antarctic polar vortices using SCIAMACHY ozone profile measurements in combination with a diabatic descent correction based on heating rate calculations. The assumptions of the methodology applied here are (a) that mixing across the vortex boundary is negligible, and (b) ozone distributions and ozone losses are horizontally constant on a given isentropic level. The errors on the derived chemical ozone loss introduced by these assumptions are difficult to quantify. They vary from winter to winter, making general quantitative statements on the magnitude of the errors impossible. Grooß et al. (2008) demonstrated that mixing across the vortex edge significantly affected the derived chemical ozone loss for the Arctic winter 2002/2003, particularly below the $475 \mathrm{~K}$ isentropic level. The chemical ozone losses for several Arctic and Antarctic winters derived in this study will be compared quantitatively to results of other studies in sections 5.1 and 5.2 , which yield conclusions on the validity of the above assumptions, at least for the winters studied.

At high latitudes during winter, solar heating is nearly absent and infrared cooling resulting from the emissions of stratospheric water vapor and carbon dioxide dominates (e.g., Siskind et al., 1998; Jucks and Salawitch, 2000). Diabatic descent of ozone-rich air into the lower polar stratosphere occurs during winter. This descent is mostly driven by the Brewer-Dobson (BD) circulation (e.g., Dobson et al., 1930; Brewer, 1949; Haynes et al., 1991; Holton et al., 1995; Rosenlof, 1995; Weber et al., 2003) and has to be corrected for when estimating the chemical ozone loss in the polar vortex.

Note, that SCIAMACHY limb observations provide ozone profile measurements only in the sunlit part of the atmosphere. This leads to a poorer sampling of the polar vortex during the early phases of the periods analyzed. Violations of the above assumptions lead to uncertainties in the derived chemical ozone losses.

The two hemispheres exhibit significant differences in terms of the dynamics of the polar winter stratosphere and the observed chemical ozone losses inside the vortices. Depletion of ozone in the Arctic lower stratosphere during winter and spring has been detected in some winters when the lower stratosphere was very cold and a stable vortex prevailed for 
extended periods. The influence of several warmings typically leads to perturbation and finally break-up of the Arctic polar vortex by mid-April at the latest. The Antarctic lower stratosphere during winter is characterized by lower temperatures and a generally more stable polar vortex compared to the Arctic polar winter (e.g., Solomon, 1999).

The manuscript is structured as follows. The SCIAMACHY instrument, whose observations are employed in this study, is briefly described in Sect. 2. A summary of the novel ozone profile retrieval using the SCIATRAN radiative transfer model and the detection of PSCs from SCIAMACHY limb-scatter observations are also provided in this section. Section 3 discusses the determination of the polar vortex boundaries in both hemispheres during winter/spring. The inferred lower stratospheric chemical ozone losses in both hemispheres between 2002 and 2009 are presented and discussed in Sect. 4.

Section 5 deals with comparisons of the chemical ozone losses derived from SCIAMACHY limb-scatter observations with other studies for the Arctic (section 5.1) and the Antarctic (Sect. 5.2) winters. Conclusions are presented in the last section.

\section{The SCIAMACHY instrument and data products}

The Scanning Imaging Absorption SpectroMeter for Atmospheric CHartographY (SCIAMACHY) onboard the European environmental satellite Envisat was launched in March 2002 (e.g., Burrows et al., 1995; Bovensmann et al., 1999). Envisat is in a near-polar sun-synchronous orbit at $800 \mathrm{~km}$ mean altitude and has a 10:00 a.m. local time descending node. For latitudes equatorward of $60^{\circ}$ in both hemispheres the local time of the SCIAMACHY observations used here is within one hour of 10:00 a.m. At the highest latitudes used here (about $80^{\circ}$ ) the local times of the measurements are about 1 p.m. in the northern hemisphere and about 7 a.m. in the southern hemisphere. Envisat completes about 14.6 orbits per day, achieves full coverage of the sunlit part of the earth in 6 days and has a ground track repeat cycle of 35 days. SCIAMACHY is an 8-channel grating spectrometer covering the UV/visible/SWIR spectral range between $214 \mathrm{~nm}$ and $2386 \mathrm{~nm}$ with a spectral resolution varying between $0.24 \mathrm{~nm}$ and $1.48 \mathrm{~nm}$. SCIAMACHY measures scattered and reflected solar radiation in limb and nadir viewing geometry as well as transmitted solar or lunar radiation in occultation mode. In limb viewing geometry the SCIAMACHY instrument scans vertically from the surface up to the top of the atmosphere (about $100 \mathrm{~km}$ tangent height) in elevation steps of about $3.3 \mathrm{~km}$. Further information on the SCIAMACHY instrument and the mission goals can be found in Bovensmann et al. (1999) and Burrows et al. (1995). In this study we use the ozone profile and the PSC data products retrieved from SCIAMACHY limb-scatter observations. Communication has been lost with the Envisat platform by ESA on the 8th April 2012. This was unexpected and in the unlikely event that contact to Envisat is restored, SCIAMACHY may measure again.

\subsection{Ozone profile retrievals from SCIAMACHY limb-scatter measurements}

We use the version 2.0 ozone profile data product retrieved from SCIAMACHY limb-scatter measurements at IUP Bremen. A detailed description of the retrieval method was recently provided in Sonkaew et al. (2009). The retrieval is an extension of the method applied by von Savigny et al. (2005a) and combines spectral information from the Hartley, Huggins and Chappuis absorption bands of ozone allowing the retrieval of vertical ozone profiles from the lower stratosphere up to the lower mesosphere $(15-65 \mathrm{~km})$ with a vertical resolution of about $4-4.5 \mathrm{~km}$. Note that this vertical resolution corresponds to about $100 \mathrm{~K}$ in terms of potential temperature. Vertical structures in chemical ozone loss occurring at smaller vertical scales cannot be resolved with SCIAMACHY limb scatter observations. The retrieval is based on the software package SCIATRAN 2.2 (Rozanov et al., 2005; Rozanov, 2008). Spectral information in the Hartley and Huggins bands of ozone is measured in SCIAMACHY channels 1 and 2, ranging from $214 \mathrm{~nm}$ to $314 \mathrm{~nm}$, and from $309 \mathrm{~nm}$ to $404 \mathrm{~nm}$, respectively. The Chappuis bands are covered by channels 3 and 4 ranging from $394 \mathrm{~nm}$ to $620 \mathrm{~nm}$ and from $604 \mathrm{~nm}$ to $805 \mathrm{~nm}$, respectively. SCIAMACHY Level 1 version 6.03 data is used as a basis for the analysis in this study including the most recent tangent height correction scheme. The Stratozone 2.0 data product provides the vertical variation of ozone concentration (in molecules $\mathrm{cm}^{-3}$ ) on a regular $1 \mathrm{~km}$ altitude grid. Version 2.0 of this data product has been validated with SAGE II and HALOE solar occultation measurements showing agreement typically within $10 \%$ or better in the stratosphere - including at high latitudes ( $\mathrm{L}$. Amekudzi, personal communication, 2009). This data set has also been used in combination with other stratospheric ozone time series for the ozone trend studies recently published by Steinbrecht et al. (2009) and Jones et al. (2009).

For further processing, the ozone concentrations were converted to ozone mixing ratios using pressure and temperature profiles from the UKMO stratospheric analysis data set (Swinbank and O'Neill, 1994) for the time and location of each SCIAMACHY limb measurement, followed by an interpolation onto a potential temperature $(\theta)$ grid.

\subsection{Detection of polar stratospheric clouds}

Polar stratospheric clouds (PSCs) are also detected using SCIAMACHY limb-scatter observations with a colour-index approach employing two weakly absorbing wavelengths in the near IR (750 nm and $1090 \mathrm{~nm})$ as described in von Savigny et al. (2005b). PSC results will be presented as PSC occurrence rate, which is a dimensionless quantity and is 
defined as the ratio of the number of observations with PSC detections and the total number of SCIAMACHY limb measurements - in a given latitude/longitude bin of $5^{\circ} \times 5^{\circ}$. As demonstrated in von Savigny et al. (2005b) the detections are robust with very few PSC detections at temperatures exceeding $200 \mathrm{~K}$. Unfortunately, $\mathrm{H}_{2} \mathrm{SO}_{4}$ and $\mathrm{HNO}_{3}$ have no strong spectral signatures in the spectral range covered by SCIAMACHY. Therefore, the identification of different PSC types (in particular the distinction between type Ia and Ib) is challenging. The possibility to identify type II PSCs exploiting the $\mathrm{H}_{2} \mathrm{O}$ ice absorption feature in the near-IR is currently investigated.

\section{Vortex position}

The extent of the polar vortex can be determined using the modified potential vorticity (MPV). Following Lait (1994) the modified potential vorticity (MPV) is defined by

$\mathrm{MPV}=\mathrm{PV}\left(\frac{\theta}{475 \mathrm{~K}}\right)^{-\frac{9}{2}}$

with $\theta$ being the potential temperature. MPV removes much of the altitude dependence of potential vorticity by introducing a physically meaningful scaling factor, $\left(\frac{\theta}{475 \mathrm{~K}}\right)^{-\frac{9}{2}}$. MPV is given in potential vorticity units with $1 \mathrm{PVU}=1 \times 10^{-6} \mathrm{~m}^{2} \mathrm{~s}^{-1} \mathrm{~K} \mathrm{~kg}^{-1}$. The vortex boundary is defined by the maximum in the PV gradient and nearly coincides with the region of maximum wind speed and is typically in the range of 30-42 PVU (e.g., Nash et al., 1996; Eichmann et al., 2002; Christensen et al., 2005). In this study, air masses with absolute MPV values exceeding $38 \mathrm{PVU}$ are considered to be inside the vortex for both hemispheres. We calculated potential vorticity and modified potential vorticity at isentropic levels between $450 \mathrm{~K}$ and $600 \mathrm{~K}$ (in steps of $25 \mathrm{~K}$ ) using pressure, temperature, zonal and meridional wind profiles taken from UKMO assimilated stratospheric data. These isentropic levels correspond to altitudes of about $15-22.5 \mathrm{~km}$. Lower altitudes were not investigated in this study, because of the reduced sensitivity of the SCIAMACHY ozone profile retrievals below $15 \mathrm{~km}$.

In general, the two hemispheres exhibit significant differences in terms of stratospheric dynamics. During undisturbed winters the Arctic polar vortex can become very cold and the vortex can prevail from November to April. By mid-April the influence of several warmings typically leads to severe perturbations and the break-up of the Arctic vortex. The Antarctic vortex in comparison is characterized by a longer duration, larger extent, and higher stability. This is because the Rossby wave activity - driven by land-sea contrasts and topography - is generally stronger and more variable in the Northern Hemisphere than in the Southern Hemisphere (e.g., Holton and Alexander, 2000).

Figure 1 shows the daily and zonal mean modified potential vorticity values averaged over $5^{\circ}$ latitude bins in the Arctic stratosphere region sampled at the geolocations of SCIAMACHY observations and at the $475 \mathrm{~K}$ isentropic level from October to April of the winters 2002/2003 to $2008 / 2009$. SCIAMACHY typically starts sampling the Arctic polar vortex in late December/early January - as illustrated in Fig. 2 showing the daily and zonal maximum modified potential vorticity - when the vortex becomes illuminated by the sun and limb-scatter observations are possible again. In other words, the SCIAMACHY limb scatter observations do not sample the entire polar vortex throughout polar winter/spring, as is obvious in Fig. 1 and the vortex average chemical ozone losses derived in the following are based on the assumption of horizontal homogeneity within the vortex.

A strong polar vortex did not form in every year as can be clearly seen in Fig. 1 . The colder winters 2002/2003, 2004/2005, 2006/2007 and 2007/2008 show relatively large averaged modified potential vorticity values compared to the warmer winters 2003/2004, 2005/2006 and 2008/2009. The appearance of high potential vorticity is in good correspondence with stratospheric temperature data, e.g., from Sounding of the Atmosphere using Broadband Emission Radiometry (SABER) instrument observations (Remsberg et al., 2008; Fussen and López-Puertas, 2009), and from the National Centers for Environmental Prediction (NCEP) (CPC, 2009). They showed that extended periods of temperatures less than $200 \mathrm{~K}$ in the lower polar stratosphere (around 18 $-20 \mathrm{~km}$ ) were observed during northern winters 2002/2003, 2004/2005, 2006/2007, and 2007/2008. In the Arctic winters 2003/2004, 2005/2006, and 2008/2009 major stratospheric sudden warmings (SSWs) occurred. These events correspond to the sudden drop in enhanced potential vorticity occurring in the first half of February in 2004, 2006 and 2009. The major SSWs penetrated from the middle stratosphere to the lower stratosphere and severely disturbed the polar vortex and PSC area as reported by, e.g., Manney et al. (2005a, 2009); Sathishkumar et al. (2009) and Kuttippurath et al. (2010a).

Figure 3 shows the daily and zonal mean modified potential vorticity values in the Antarctic stratosphere at the $475 \mathrm{~K}$ isentropic level and sampled at geolocations of SCIAMACHY observations for the period May to December, 2002-2008. The figure shows that the polar vortex is essentially limited to latitudes poleward of $55^{\circ}-60^{\circ} \mathrm{S}$. Obviously, there is much less inter-annual variability of the southern polar winter stratosphere as compared to the Northern Hemisphere. Note, that SCIAMACHY cannot observe southern high latitudes during June to July - because solar radiation is required for the observations - thus the initial formation of the polar vortex does not appear in Fig. 3. It is worth noting that a weak polar vortex can be clearly seen in Fig. 3 during spring 2002. This year was characterized by a very unusual phenomenon in the Southern Hemisphere, i.e., the first observed mid-winter major stratospheric warming in the Southern Hemisphere (e.g., Varotsos, 2002; Baldwin et al., 2003; 

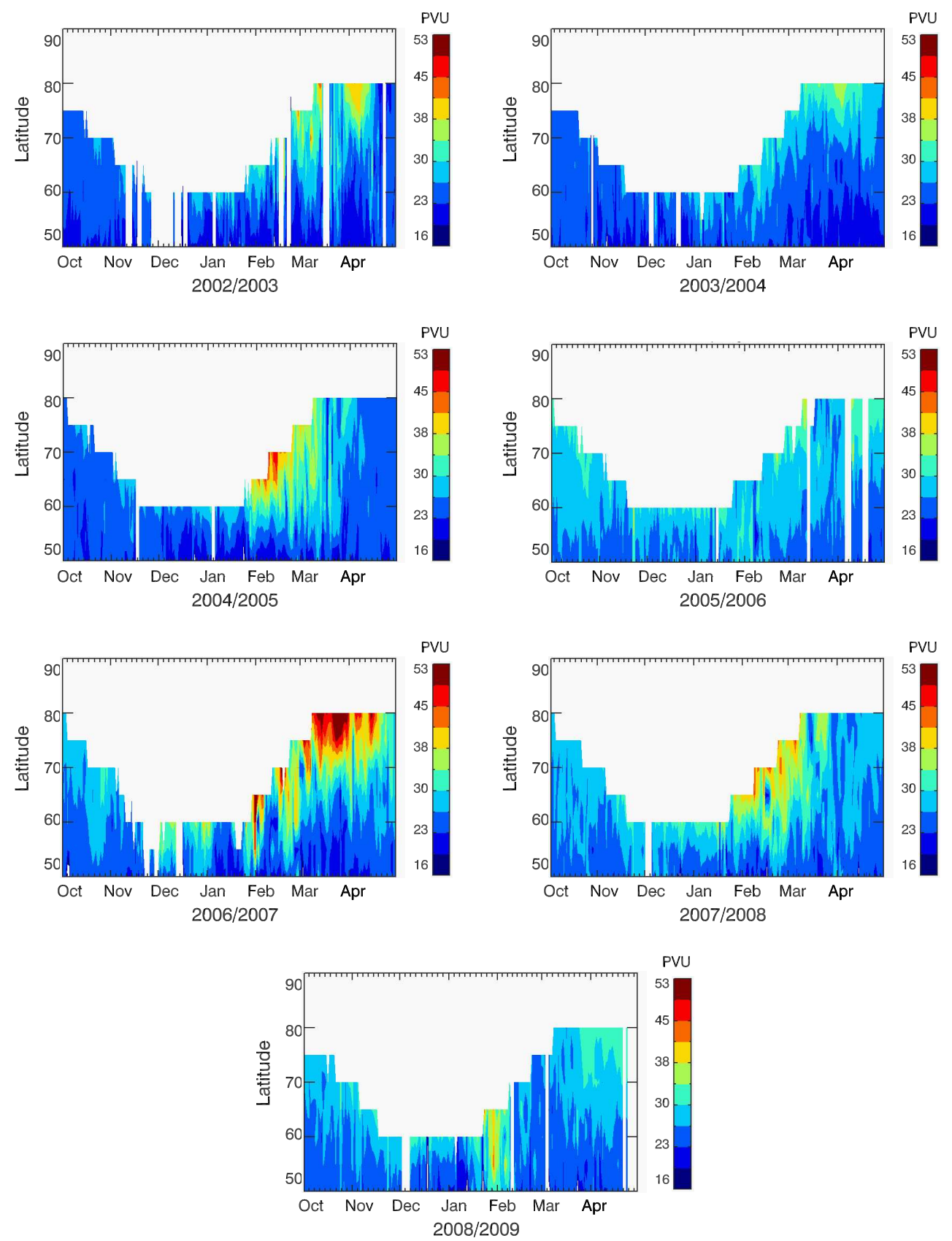

Fig. 1. Daily and zonally averaged modified potential vorticity at the $475 \mathrm{~K}$ isentropic level in the Arctic stratosphere for latitudes of SCIAMACHY observations in 2002-2009 during winter/spring (given in potential vorticity units (PVU)). Data averaged over $5^{\circ}$ latitude bins.

Hoppel et al., 2003; Kushner and Polvani, 2004; Bodeker et al., 2005; IPCC/TEAP, 2005; Newman and Nash, 2005; Ricaud et al., 2005; Konopka et al., 2005; Manney et al., 2005 b; von Savigny et al., 2005a). This major warming resulted from anomalously strong planetary wave activity in the Southern Hemisphere which caused a split of the polar vortex into two parts associated with a splitting of the ozone hole. The overall size of the ozone hole decreased to only about $10 \%$ of its usual value for a few days in late September (Stolarski et al., 2005) before a single vortex reformed.

From the averaged modified potential vorticity shown in Figs. 1 and 3 it is evident that SCIAMACHY does not sample the entire polar vortex, as mentioned above. This is one of the basic limitations of using limb scatter or solar occultation observations for determining chemical ozone losses and 

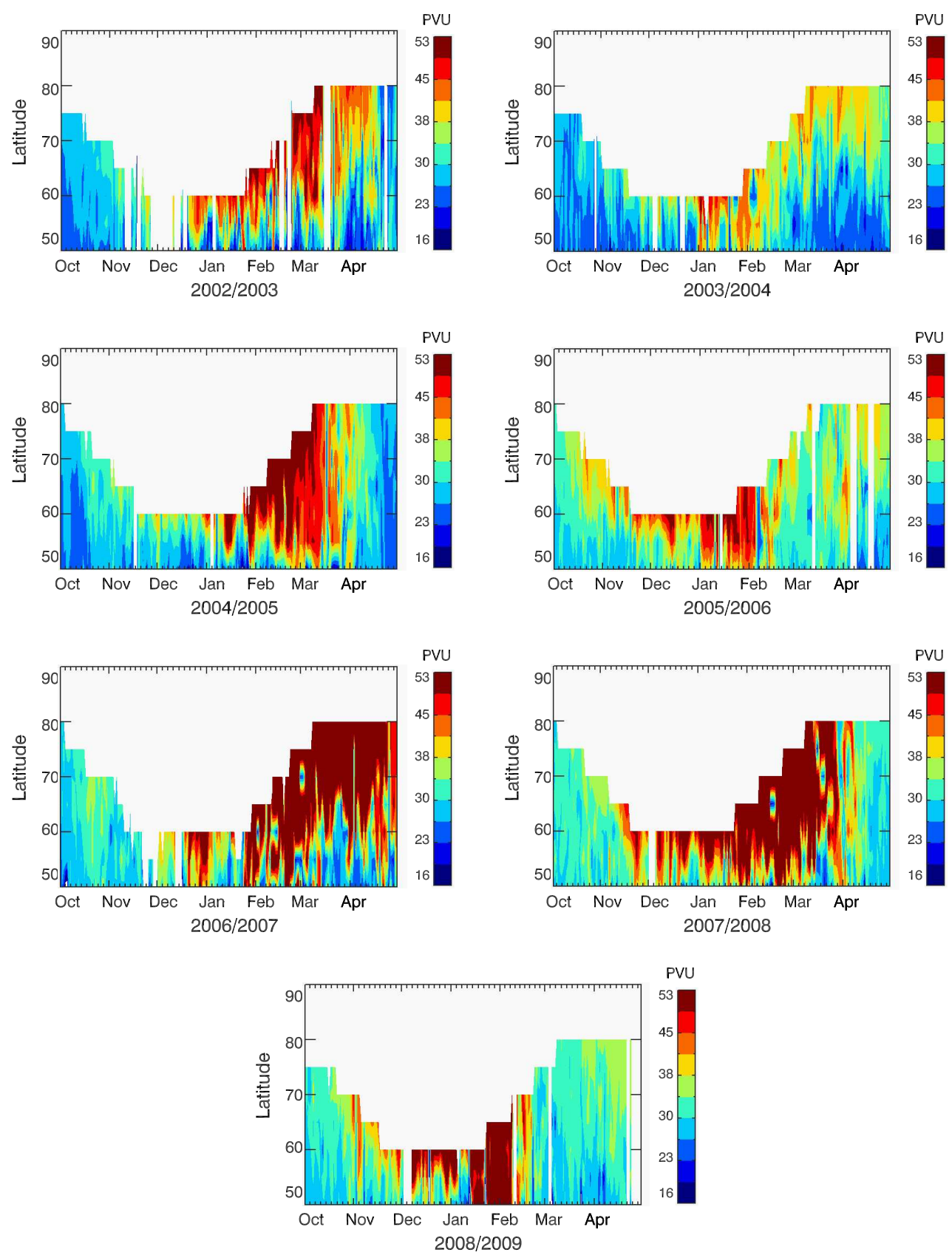

Fig. 2. Daily and zonal maximum modified potential vorticity at the $475 \mathrm{~K}$ isentropic level in the Arctic stratosphere for latitudes of SCIAMACHY observations in 2002-2009 during winter/spring (given in potential vorticity units (PVU)). Data averaged over $5^{\circ}$ latitude bins.

other studies are also affected by this (e.g. Eichmann et al., 2002; Hoppel et al., 2003; Jin et al., 2006).

It is also worth noting that there are more individual SCIAMACHY observations within the polar vortices than suggested by Figs. 1 and 3, because the figures show zonally averaged and latitudinally binned MPV. Even if the zonal average is below the MPV threshold, there may be measurements located inside the vortex as demonstrated in Fig. 2, showing the daily and zonal maximum MPV at the 475 isentropic level. The difference between the zonally averaged and maximum MPV is a consequence of the asymmetry of the polar vortex with respect to the North pole. 

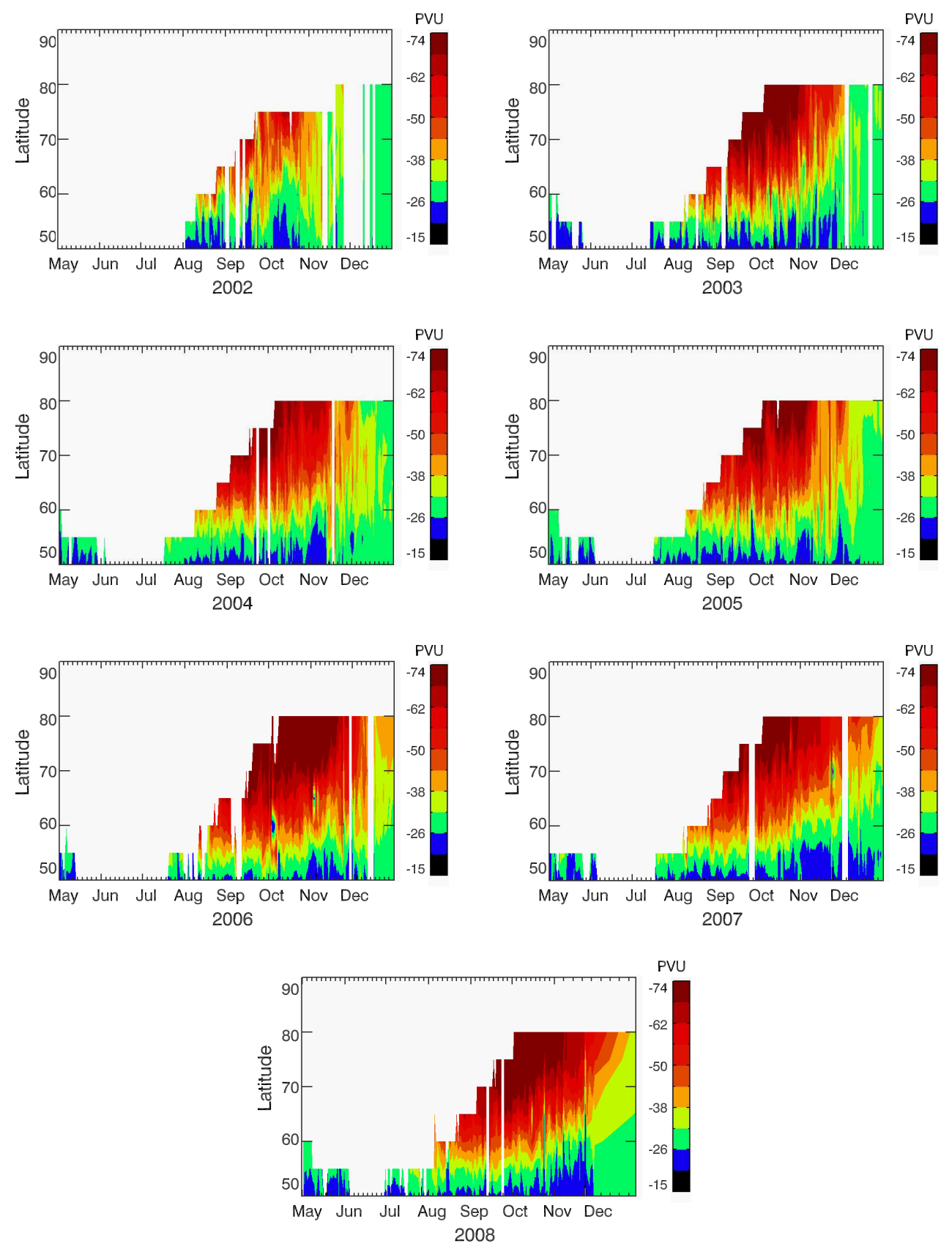

Fig. 3. Daily and zonally averaged modified potential vorticity at the $475 \mathrm{~K}$ isentropic level in the Antarctic stratosphere for the latitudes of SCIAMACHY observations in 2002-2008 during winter/spring.

\section{Determination of chemical ozone loss with a vortex average method}

We determine the mean ozone mixing ratios in the $450 \mathrm{~K}-$ $600 \mathrm{~K}$ isentropic level range (in steps of $25 \mathrm{~K}$ ) taking an average over all SCIAMACHY observations inside the polar vortex on a given day. The algorithm used for calculating the chemical ozone loss is the SODD (SCIAMACHY Ozone and Diabatic Descent) program package, which is based on the
FUDD (FUrm ozone and Diabatic Descent - where FURM stands for FUll Retrieval Method, Hoogen et al., 1999) that has initially been developed to calculate the chemical ozone loss from GOME (Global Ozone Monitoring Experiment) ozone profile retrievals (Eichmann et al., 2002). In this work, the SODD program package was adapted to SCIAMACHY limb observations and extended to calculate the chemical ozone loss in the Antarctic polar vortex in addition to the Arctic. The conceptual flow to determine the chemical ozone 
loss inside the polar vortices at a given isentropic level is as follows:

1. Using the vortex criterion described in Sect. 3 we select all SCIAMACHY ozone profile measurements inside the polar vortex on a given day. These ozone profiles - already projected onto a potential temperature grid are then averaged on each level yielding the daily mean ozone mixing ratio profiles between 450 and $600 \mathrm{~K}$ potential temperature.

2. As a result of diabatic descent (or possibly ascent) the ozone mixing ratio at a given isentropic level may also change. The temporal change in ozone mixing ratio due to diabatic vertial motion, $\frac{\partial \mathrm{O}_{3}^{d}}{\partial t}$, is calculated using the following equation (e.g., Braathen et al., 1994; Sinnhuber et al., 1998; Eichmann et al., 2002):

$$
\frac{\partial \mathrm{O}_{3}^{d}}{\partial t}=-Q\left(\frac{p_{0}}{p}\right)^{\kappa} \frac{\partial \mathrm{O}_{3}}{\partial \theta}
$$

with $Q$ being the diabatic heating rate, $\frac{\partial \mathrm{O}_{3}}{\partial \theta}$ being the partial derivative of the ozone mixing ratio with respect to potential temperature $(\theta), p$ and $p_{0}$ are the pressures at the considered isentropic level and the surface, respectively, and $\kappa=2 / 7$ is the ratio of dry air gas constant and specific heat capacity at constant pressure. We note that the absolute of the exponent $-9 / 2$ in the definition of MPV (Eq. 1) is related to $\kappa$ via $\theta^{\left(\frac{\kappa+1}{\kappa}\right)}=\theta^{\left(\frac{9}{2}\right)}$, as described by Müller and Günther (2003). The diabatic heating rate at each isentropic level considered is calculated with the MIDRAD radiative transfer model (Shine, 1991) that uses temperature and pressure profiles taken from the UKMO stratospheric assimilation. MIDRAD is run for conditions at the geolocations of all SCIAMACHY observations on a given day. Information on the short wavelength absorption by ozone and the long wavelength absorption and emission by water vapor and carbon dioxide in the stratosphere are required for the calculation. The $\mathrm{CO}_{2}$ mixing ratio is assumed to be constant at a value of 378 ppmv and the water vapour profiles are taken from the UARS HALOE climatology (Randel et al., 1998) as in Eichmann et al. (2002). The ozone profiles used in the MIDRAD calculations are from SCIAMACHY observations.

3. The accumulated ozone abundances from the daily averaged diabatic ozone descent are calculated at each isentropic level starting from a chosen date and assuming that diabatic descent is the dominating effect.

4. Subtracting the dynamically accumulated ozone from the averaged observed vortex average mixing ratios yields the chemical ozone loss. This implies that the approach is based on the assumption that the air masses are well contained inside the polar vortex, i.e., transport across the vortex boundary is neglected.

\subsection{Arctic chemical ozone loss}

Figure 4a shows daily averaged ozone mixing ratios at the $475 \mathrm{~K}$ isentropic level derived from all SCIAMACHY limb measurements inside the Arctic polar vortex for all available years. The solid lines show the resulting time series smoothed with a 3-day boxcar function.

As discussed above SCIAMACHY starts to sample the Arctic polar vortex on different dates in different years. In order to provide comparable chemical ozone loss estimates common start dates are chosen for most of the results presented below. The chemical ozone losses in the Arctic polar vortex are determined for two different periods:

a. The period starting on January 22 and ending on the last day with observations at locations with MPV values exceeding $38 \mathrm{PVU}$ in the investigated isentrope range. The reference period used here is 19-25 January of each year.

b. A 1-month period from 1 February to 1 March of each year.

Results for both periods are presented in Table 1. The daily changes of ozone mixing ratio due to vertical transport, associated with diabatic cooling, are determined at each isentropic level. The computed daily ozone change (DOC) rates due to diabatic descent (or ascent) (in ppbv day ${ }^{-1}$ ) at the $475 \mathrm{~K}$ isentropic level for the Arctic vortex are shown in panel $b$ of Fig. 4. Apparently the daily ozone change rates inside the Arctic vortex vary from year to year. For example, in March of 2005, unusually large dynamically induced ozone changes at the $475 \mathrm{~K}$ isentropic level were observed (panel b of Fig. 4). Episodes with negative diabatic ozone change values were detected in 2004 and 2006 (dark and light blue lines, respectively). These periods correspond to the unique characteristics of stratospheric warmings (e.g., Manney et al., 2005a; Hoppel et al., 2008; Kuttippurath et al., 2010a).

The accumulated diabatic ozone changes were calculated from the beginning of each studied period and are displayed as dashed lines in panel c of Fig. 4 for the Arctic polar vortex. The chemical ozone loss inside the vortex is then determined by subtracting the modelled accumulated diabatic ozone increase from the observed vortex average ozone mixing ratio. The resulting chemical ozone loss time series are shown in panel d of Fig. 4. Panel e shows the relative chemical ozone losses in percent referenced to the start dates listed in Table 1.

The absolute and relative ozone loss time series shown in panels $d$ and e of Fig. 4 exhibit oscillations and periods with decreasing ozone losses. The origin of these effects is not fully established but is likely related to the neglected transport across the vortex boundary (e.g. Grooß et al., 2008; El Amraoui et al., 2008) as well as horizontal 



e)

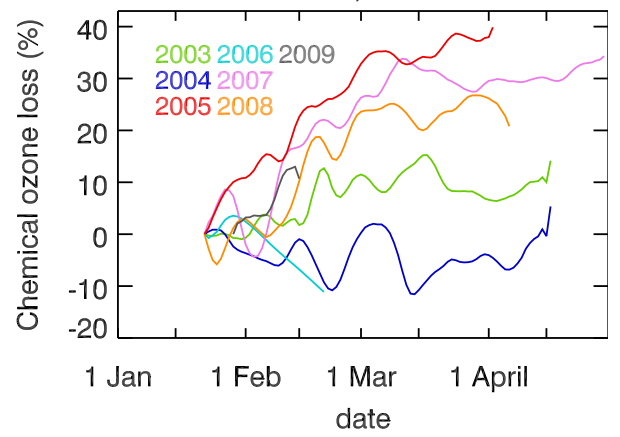

Fig. 4. Chemical ozone loss results for the Arctic polar vortices 2002/2003 to 2008/2009 at the $475 \mathrm{~K}$ isentropic level and the periods listed in Table 1. (a) Observed vortex average ozone mixing ratio time series. The grey-shading indicates the standard deviations of the individual ozone measurements inside the vortex about the daily mean (for 2005 only, for reasons of clarity). Days with missing data and days where the SCIAMACHY instrument did not sample the vortex are filled using a spline interpolation. The solid and open circles show the original and interpolated data, respectively. (b) Daily ozone mixing ratio change (DOC) due to diabatic descent determined with MIDRAD model simulations. The time series are shown for the time periods listed in Table 1. (c) Accumulated ozone mixing ratio from daily diabatic descent (dashed lines) and the observed ozone mixing ratio time series (solid lines). (d) Chemical ozone losses in ppmv. (e) Chemical ozone loss in percent relative to the start days listed in Table 1. The grey-shading in panels (b) and (d) corresponds to the 1- $\sigma$ uncertainty based on the standard deviation of the ozone mixing ratio about the daily mean (only exemplarily shown for 2005).

inhomogeneities inside the polar vortex in combination with the fact that SCIAMACHY does not sample in the entire polar vortex. Fig. 4 demonstrates that the apparent oscillations in the chemical ozone loss time series originate from oscillations in the vortex averaged ozone time series. Several other studies also show oscillations in the vortex averaged ozone time series (e.g., Eichmann et al. (2002) (Fig. 5), Rex et al. (2006) (Fig. 1e), Feng et al. (2005) (Fig. 2), and Kuttippurath et al. (2010a) (Fig. 2). If mixing across the vortex edge, ozone inhomogeneities inside the vortex and inhomogeneous sampling cannot be accounted for, e.g. using model simulations, these effects may lead to apparent oscillations in the derived ozone loss time series. Rex et al. (2006) demonstrate (their Fig. 1e) that oscillations in vortex averaged ozone at the $450 \mathrm{~K}$ level during the 2004/2005 winter observed by both ozone sondes and satellite solar occultation observations can be explained by ozone inhomogeneities within the 
Table 1. The chemical ozone loss rates and accumulated ozone losses in the Arctic polar vortex between the $450 \mathrm{~K}$ and $600 \mathrm{~K}$ isentropic levels for the winters 2002/2003 to 2008/2009. The seasons with sudden stratospheric warmings are shown separately at the bottom of the table. Note that the ozone losses below about $550 \mathrm{~K}$ potential temperature are mainly driven by reactive halogen compounds formed by heterogeneous reactions, whereas the losses above this level are driven by enhanced $\mathrm{NO}_{\mathrm{x}}$ and occur near the end of spring.

\begin{tabular}{|c|c|c|c|c|c|}
\hline \multirow[t]{2}{*}{ Year } & \multicolumn{2}{|c|}{ Studied period } & \multicolumn{2}{|c|}{ Chemical $\mathrm{O}_{3}$ loss at $475 \mathrm{~K}$} & \multirow{2}{*}{$\begin{array}{l}\text { Pot. temp. with max. } \mathrm{O}_{3} \text { loss } \\
\text { and } \mathrm{O}_{3} \operatorname{loss}^{4}(\mathrm{~K}(\mathrm{ppmv}))\end{array}$} \\
\hline & Start date & End date & accumulated $^{1,(2)}$ (ppmv) & $\operatorname{average}^{3}\left(\mathrm{ppbv}_{\mathrm{day}}{ }^{-1}\right)$ & \\
\hline 2003 & $22 \mathrm{Jan}$ & $16 \mathrm{Apr}$ & $-0.44(-0.38)$ & -5.1 & $600(-1.15)$ \\
\hline 2004 & 22 Jan & 31 May & $-0.23(+0.17)$ & -2.7 & $600(-1.29)$ \\
\hline 2005 & 22 Jan & $2 \mathrm{Apr}$ & $-1.69(-0.93)$ & -23.8 & $450(-1.75)$ \\
\hline 2007 & 22 Jan & 24 Apr & $-1.41(-1.16)$ & -11.6 & $600(-2.06)$ \\
\hline 2008 & 22 Jan & $6 \mathrm{Apr}$ & $-0.78(-0.77)$ & -10.4 & $600(-1.45)$ \\
\hline 2006 & $22 \mathrm{Jan}$ & $21 \mathrm{Feb}$ & $+0.45(-)$ & +16.7 & $600(-1.86)$ \\
\hline 2009 & 29 Jan & $19 \mathrm{Feb}$ & $-0.45(-)$ & -20.4 & $450(-1.03)$ \\
\hline
\end{tabular}

\footnotetext{
1 accumulated over the entire period studied, using 19-25 January as reference period;

2 accumulated over one month from 1 February to 1 March, except for 2006 and 2009 when data are not available for the entire month;

3 daily loss rate averaged over period studied;

4 isentropic level with maximum accumulated ozone loss during period studied and the accumulated ozone loss (Note that the ozone loss at $600 \mathrm{~K}$ in 2006 was determined up to 24 April).
}

vortex in combination with inhomogeneous sampling of the polar vortex.

The chemical ozone losses inside the Arctic polar vortex exhibit a strong inter-annual variability. The maximum absolute ozone loss derived for the winters 2002/2003 to 2008/2009 inside the Arctic vortex is about 1.7 ppmv for period a) discussed above (corresponding to relative losses of about 35\%) and occurred in March of the year 2005. The winter with the second largest chemical ozone losses at the $475 \mathrm{~K}$ isentropic level was 2006/2007 with losses reaching about 1.4 ppmv (or about 30\% relative loss) in April 2007. In March 2008 an absolute loss at the $475 \mathrm{~K}$ isentropic level inside the Arctic vortex of about $0.8 \mathrm{ppmv}$ is retrieved (20$25 \%$ ) and about 0.4 ppmv for winter $2002 / 2003$. For spring 2004 and 2006 there are no indications for significant chemical ozone losses and even negative values of ozone loss were observed. The negative values may be caused by transport across the vortex edge or violation of the homogeneity assumption.

The chemical ozone losses were also computed at different isentropic levels ( $450 \mathrm{~K}-600 \mathrm{~K}$, in $25 \mathrm{~K}$ steps). The absolute ozone losses in terms of mixing ratio as a function of time and potential temperature for the Arctic region are presented as contour plots in Fig. 5. The start date for the determination of the ozone losses is 22 January for each year except 2009, when 29 January was used (see also Table 1). The derived daily chemical ozone losses for the Arctic polar vortex are summarized in Table 1. The accumulated ozone losses in ppmv at the $475 \mathrm{~K}$ isentropic level over the entire considered period are presented in the 4th column of Table 1. The ozone losses over the one month period from 1 February to 1 March are shown in parentheses. The daily ozone loss rates, in ppbv per day, were determined by taking the average loss rate over the considered periods (5th column in Table 1 ). The maxi- mum accumulated ozone loss and the isentropic level where it occurred is shown in the last column of Table 1. The results presented in Table 1 show that the largest accumulated chemical ozone losses inside the Arctic polar vortex and for the periods considered occurred in 2005 and 2007.

In mid-February 2009, a SSW occurred and limited the chemical ozone depletion processes. A SSW event also occurred in early 2006 but it affected the lower stratosphere not as strongly as in 2009 . This event has been reported by Kuttippurath et al. (2010a) and Manney et al. (2009).

Significant chemical ozone loss rates over the Arctic region at the $475 \mathrm{~K}$ isentropic level were found in 2005, 2007, 2008 and 2003 with the years being listed in decreasing order in terms of ozone loss shown in the 4th column of Table 1.

The substantial ozone losses in the 2004/2005 and 2006/2007 Arctic winter stratosphere are obvious in Fig. 5. According to the panels of this figure, peak ozone losses reaching about 1.5 ppmv occurred in March of both years in the lower stratosphere between the $450 \mathrm{~K}$ and $500 \mathrm{~K}$ isentropic levels. The largest accumulated ozone loss for isentropic levels below $550 \mathrm{~K}$ and for the period from midJanuary to beginning of April was found for the 2004/2005 winter as shown in Fig. 5 and Table 1.

A noteworthy feature in Fig. 5 is the increase in chemical ozone losses in late March and April above $550 \mathrm{~K}$ that occurs in most years analyzed. These ozone losses above the $550 \mathrm{~K}$ isentropic level are attributed to catalytic ozone destruction due to $\mathrm{NO}_{\mathrm{x}}$ and have been reported in several earlier studies (Grooß and Müller, 2007; Grooß et al., 2005; Konopka et al., 2007). Konopka et al. (2007) suggested that the substantial ozone losses in the upper part of the polar vortex in the winter $2002 / 03$ are caused by the horizontal transport of subtropical $\mathrm{NO}_{\mathrm{x}}$ rather than the descent of $\mathrm{NO}_{\mathrm{x}}$ - rich air masses from the mesosphere. The largest ozone losses of about $2.1 \mathrm{ppmv}$ 

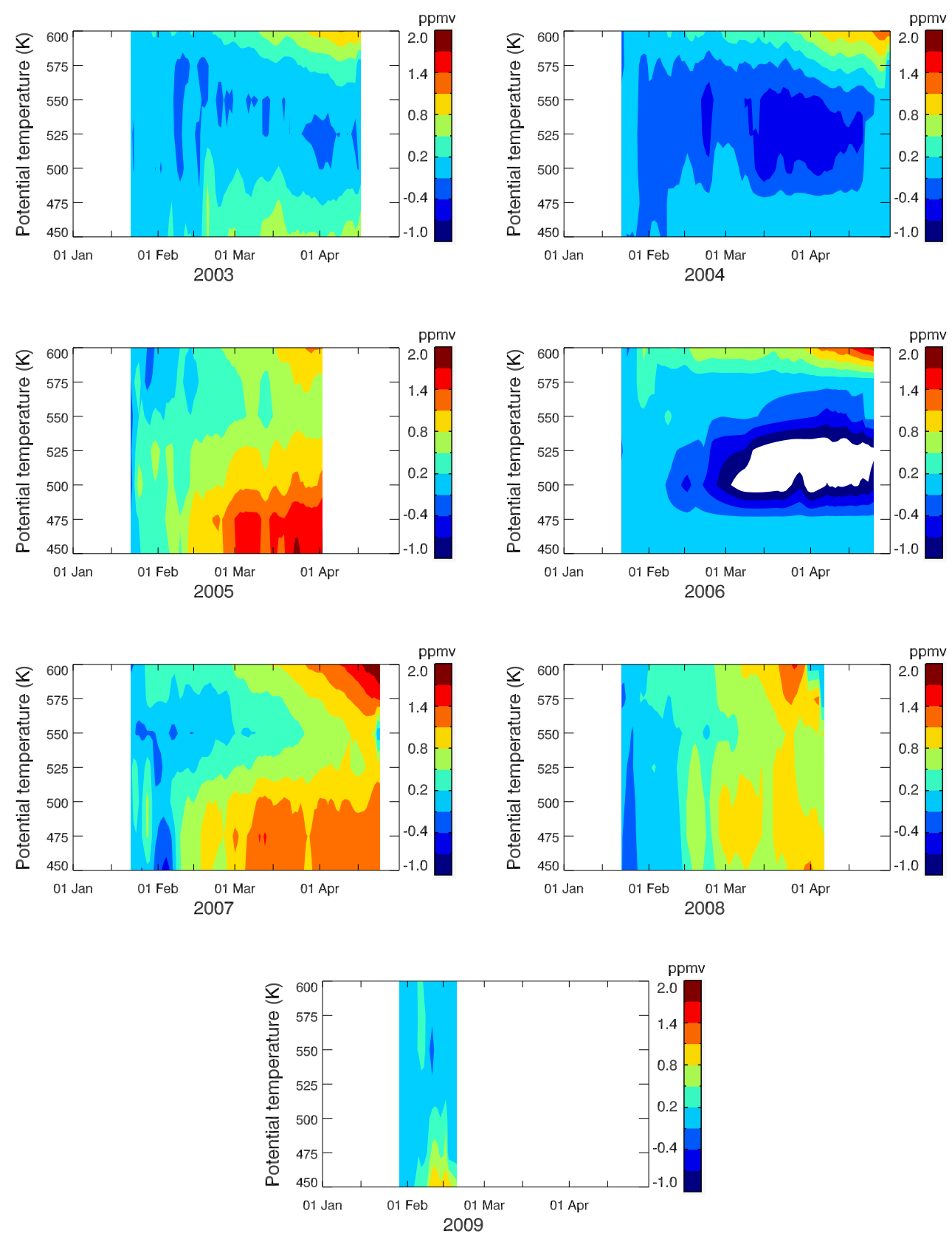

Fig. 5. Derived vortex average ozone losses as a function of time and potential temperature for the winters 2002/2003 to 2008/2009 in the Arctic winter stratosphere. With the exception of 2009 the reference period is January $19-25$ and the chemical ozone losses are determined starting on January 22 of each year (see Table 1).

were observed at $600 \mathrm{~K}$ in spring 2007 , which is consistent with Rösevall et al. (2007a) and other studies.

Indications for significant ozone depletion cannot be detected in the 2003/2004 and 2005/2006 polar vortices in the Arctic region. The data gap in 2006 between the $500 \mathrm{~K}$ and $525 \mathrm{~K}$ isentropic levels starting in early March is due to the fact that no SCIAMACHY observations are available inside the polar vortex defined by the MPV criterion introduced in Sect. 3.
In the following we will also use the derived accumulated chemical ozone loss inside the polar vortex to estimate the ozone mass loss within the polar vortex between the $450 \mathrm{~K}$ and $600 \mathrm{~K}$ isentropic levels. The spatial extent of the polar vortex for the $450-600 \mathrm{~K}$ isentrope range is extracted from the UKMO stratospheric analyses on a daily basis using the vortex criterion introduced in Sect. 3. The derived absolute chemical ozone loss at a given isentropic level is now converted to the ozone mass loss per volume and multiplied by 

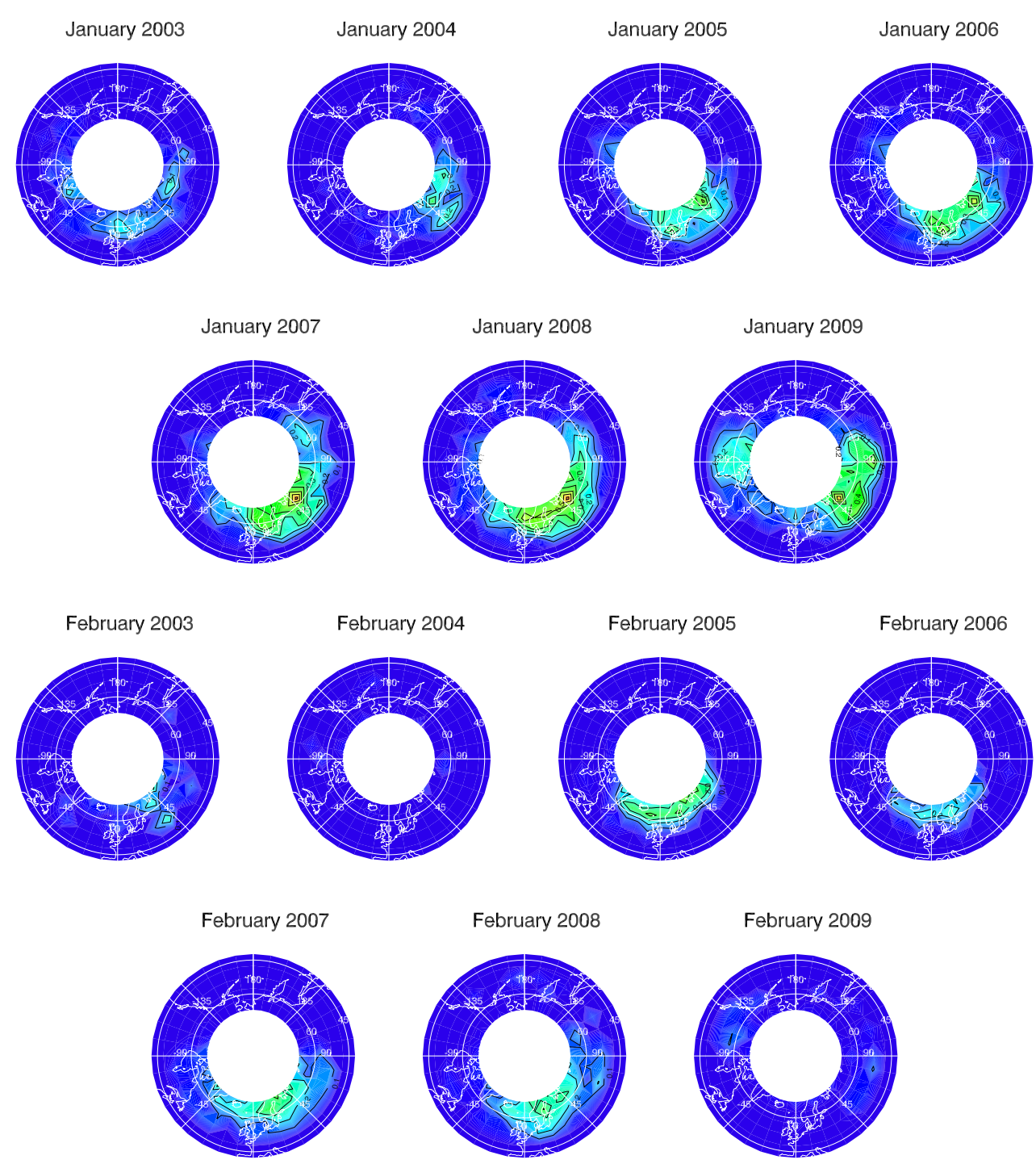

PSC occurrence rate

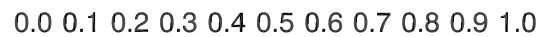

Fig. 6. Maps of PSC occurrence rates in the northern polar atmosphere for January and February of the years 2003-2009. Contour levels are drawn in steps of 0.1 . Meridians are displayed in steps of $45^{\circ}$ and latitude circles are shown for $45^{\circ} \mathrm{N}$ and $60^{\circ} \mathrm{N}$.

the spatial extent of the polar vortex area of this isentropic level. The ozone mass losses for the $450 \mathrm{~K}$ to $600 \mathrm{~K}$ levels are then integrated to determine the total ozone mass loss within the $450 \mathrm{~K}$ to $600 \mathrm{~K}$ potential temperature range. The polar vortex volume between the $450 \mathrm{~K}$ and $600 \mathrm{~K}$ isentropic levels is also determined by integration of the values for all isentropic levels.

Figure 6 shows maps of PSC occurrence rates in the Arctic for January and February of the years 2003 to 2009. Apparently there is a good qualitative agreement between PSC occurrence rates in February and the cumulative chemical ozone loss inside the Arctic vortex for the corresponding years shown in Fig. 4. For January of every year the PSC maps do not show as much inter-annual variability, but are characterized by a maximum in PSC occurrence rate between about $55^{\circ}$ and $70^{\circ} \mathrm{N}$ in the Eurasian sector. In February the largest PSC occurrence rates are observed for the winters 2004/2005, 2006/2007, and 2007/2008 which were also associated with the largest ozone losses. We note the apparent alternating behavior of low and high PSC occurrence rates and chemical ozone losses in consecutive years, with low PSC occurrence rates in 2004 and 2006, and higher occurrence 


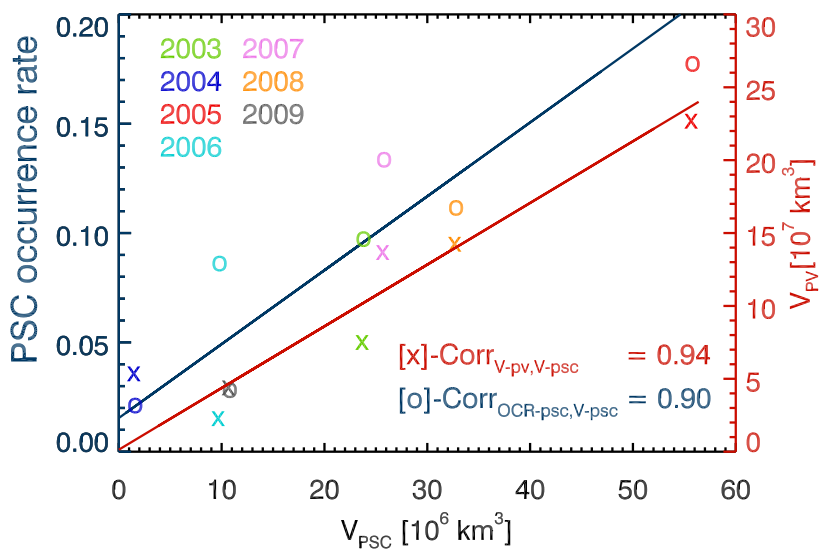

Fig. 7. Scatter plot of February mean PSC occurrence rate over the Arctic and the PSC volume taken from WMO (2011) (open circles and blue line), and scatter plot of averaged polar vortex volume from this study integrated over the 450-600 K isentropic levels over the Arctic in February and PSC volume taken from WMO (2011) (crosses and red line).

rates - compared to the following year - in 2003, 2005, and 2007. This alternating behavior is very likely related to the phase of the quasi-biennial oscillation (QBO) and is further discussed below in Sect. 5.1.

Note that we are not claiming that PSCs occurring in February are responsible for the majority of the chlorine activation eventually leading to the accumulated ozone losses. Our interpretation of the correlation is that years with high PSC occurrence rate, i.e. low temperatures in February are characterized by a stable vortex, and a lower probability of a major warming interrupting the chemical ozone loss.

Although the exact relationship between PSC occurrence rate and other related quantities, e.g. PSC volume, is difficult to establish, our results qualitatively confirm earlier studies (e.g., Rex et al., 2006; WMO , 2011). To illustrate the relationship between PSC occurrence rate and polar vortex volume determined in this study with PSC volume we use the averaged PSC volume for the period mid-December to end of March based on meteorological analyses provided by the European Centre for Medium-Range Weather Forecasts (ECMWF) as taken from WMO (2011) (Fig. 2-16 therein; for details see Rex et al. (2004)). The relationship between PSC occurrence rate in February and PSC volume is shown in Fig. 7 by the open circles and the blue linear fit. The relationship between polar vortex volume in February and PSC volume for the period mid-December until end of March is shown in Fig. 7 by the crosses and the red linear fit. Interestingly, the averaged PSC volume for a more extended time period correlates well with both the PSC occurrence rate in February as observed with SCIAMACHY and with the polar vortex volume for the $450-600 \mathrm{~K}$ isentropic range for the month of February. From Fig. 7 it is evident that the three quantities considered - PSC occurrence rate, polar vor- tex area and PSC volume - were highest for spring/winter of $2004 / 2005$ and insignificant for spring/winter of 2003/2004, 2005/2006 and 2008/2009. High correlation coefficients of 0.91 between PSC occurrence rate and PSC volume and 0.94 between polar vortex volume and PSC volume show that our findings are in good qualitative agreement with the result in WMO (2011).

The temporal variation of the Arctic polar vortex volume between the $450 \mathrm{~K}$ and $600 \mathrm{~K}$ isentropic levels for the period from 1 January to 15 April is shown in the left panel of Fig. 8. The polar vortex size in the Arctic region varies substantially from year to year. The largest polar vortex volume within the $450-600 \mathrm{~K}$ isentrope range occurred in 2005 with about $200 \times 10^{6} \mathrm{~km}^{3}$ lasting from the beginning of January until mid-March. The ozone mass loss time series are shown in the right panel of Fig. 8 with the grey shading indicating the uncertainty for 2005 . The uncertainty in the ozone mass loss is estimated from the standard deviation associated with the chemical ozone losses (shown, e.g. in Fig. 4d for the northern and in Fig. 9d for the southern hemisphere), and is based on the assumption that the uncertainty in the polar vortex volume is zero. We note that this uncertainty estimate does not necessarily include all sources of uncertainty associated with the methodology used here.

For the winter 2004/2005 the ozone mass loss reached a maximum value of about 25 million tons and dropped after mid-March, probably due to vortex erosion and enhanced mixing with mid-latitude air. For the winters 2006/2007 and 2007/2008 the ozone mass loss reached values of about 10 million tons. It must be mentioned that for the period after mid-March the determined mass losses are less reliable, because air masses from outside the vortex may be mixed into the vortex. This mixing of vortex and out-of-vortex air may also happen earlier. For the winters 2003/2004, 2005/2006 and 2008/2009 the ozone mass losses are shown only until the beginning of February, because stratospheric warmings caused a sudden decrease in polar vortex volume, and because of the non-significant chemical ozone losses during these winters.

\subsection{Antarctic chemical ozone loss}

The results for the Antarctic polar vortex are presented in Fig. 9 in a similar way as the results for the Arctic vortex shown in Fig. 4. Figure 9a shows the averaged ozone mixing ratio inside the Antarctic vortex at the $475 \mathrm{~K}$ potential temperature level for the period from 15 August to 15 November of each year. The absolute and relative chemical ozone losses are presented in panels $d$ and e of the Fig. and are determined starting on 18 August using a reference period between 15 and 22 August. Panel d of Fig. 9 shows that the ozone loss rates are larger in August and September than in October, when the chemical ozone loss stops. The chemical ozone loss during the period from 18 August to 15 November reaches about $2.5 \mathrm{ppmv}$ or $26-31 \mathrm{ppmv}^{-1 a y^{-1}}$ (averaged 
Table 2. The chemical ozone loss rates in the Antarctic polar vortex between $450 \mathrm{~K}$ and $600 \mathrm{~K}$ isentropic levels between 22 August and 15 November of the years 2002-2008. Note that while ozone losses below about $550 \mathrm{~K}$ potential temperature are mainly driven by reactive halogen compounds formed by heterogeneous reactions, the losses above this level may also be affected by enhanced $\mathrm{NO}_{\mathrm{x}}$ occurring near the end of austral spring.

\begin{tabular}{c|cc|c}
\hline \multirow{2}{*}{ Year } & \multicolumn{2}{|c|}{ Chemical $\mathrm{O}_{3}$ loss at $475 \mathrm{~K}$} & Pot. temp. with max $\mathrm{O}_{3}$ loss \\
\cline { 2 - 3 } & accumulated $^{1},(2)(\mathrm{ppmv})$ & average $^{3}\left(\mathrm{ppbv} \mathrm{day}^{-1}\right)$ & and $\mathrm{O}_{3}$ loss $^{4}(\mathrm{~K}(\mathrm{ppmv}))$ \\
\hline 2002 & $-2.43(-1.22)$ & -27.3 & $550(-3.63)$ \\
2003 & $-2.34(-1.58)$ & -26.3 & $600(-2.92)$ \\
2004 & $-2.36(-1.34)$ & -26.5 & $500(-2.52)$ \\
2005 & $-2.35(-1.47)$ & -26.4 & $600(-2.45)$ \\
2006 & $-2.31(-1.18)$ & -25.9 & $500(-2.65)$ \\
2007 & $-2.72(-1.70)$ & -30.5 & $550(-2.96)$ \\
2008 & $-2.52(-1.36)$ & -28.4 & $500(-2.74)$ \\
\hline
\end{tabular}

1 accumulated over the period from 18 August to 15 November, using 15-21 August as reference period;

2 accumulated over a one month period from 18 Aug to 18 September;

3 daily loss rate averaged over the period from 18 August to 15 November;

4 isentropic level with maximum accumulated ozone loss during period studied (18 August to 15 November) and the accumulated ozone loss.
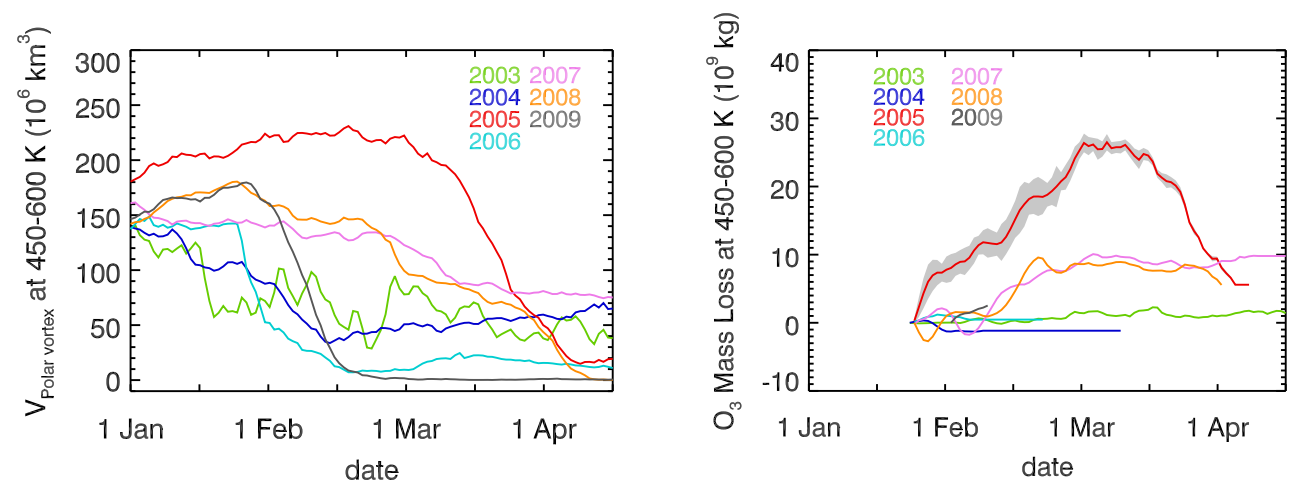

Fig. 8. Time evolution of the polar vortex volume (left panel), and the estimated ozone mass loss inside the vortex (right panel) between the $450 \mathrm{~K}$ and $600 \mathrm{~K}$ isentropic levels in the Arctic winter stratosphere. Note that the isentrope range considered here $(450$ - $600 \mathrm{~K})$ includes both halogen driven ozone loss below about $550 \mathrm{~K}$ as well as $\mathrm{NO}_{\mathrm{x}}$ driven ozone loss near $600 \mathrm{~K}$ occurring near the end of spring (see Fig. 5).

over period considered) every year as shown in panel $\mathrm{d}$ of Fig. 9 and Table 2, respectively. The relative ozone losses are shown in Fig. 9e and amount to about 70-90\% at the $475 \mathrm{~K}$ level by the end of October.

The seasonally averaged daily chemical ozone loss rates inside the Antarctic polar vortex are summarized in Table 2. The ozone loss rates for 2002-2008 show little inter-annual variability and are between about 26 and 31 ppbv per day for the whole studied period. At the $475 \mathrm{~K}$ level the inferred average ozone loss rate maximizes at about 30.5 ppbv per day in 2007. The maximum ozone losses at the $475 \mathrm{~K}$ level and the period considered were derived for 2007 with 2.72 ppmv, followed by 2008 with 2.52 ppmv. Note however, that the maximum ozone losses are usually found at higher levels at around $500-525 \mathrm{~K}$ potential temperature or above. It is worth noting that a large ozone loss inside the vortex does not necessarily imply a large ozone mass loss, because the latter also depends on the evolution of the vortex size. The ozone loss inside the polar vortex in 2002, as presented in Fig. 9, is essentially the same as in all other years considered. This result differs somewhat from the study of Hoppel et al. (2003), who found the ozone loss in the Antarctic vortex about $20 \%$ smaller than for the other years analyzed (1994-2001). It is, however, consistent with the fact that chlorine activation - as evident in for examples, OClO observations by GOME (Weber et al., 2003; Richter et al., 2005) and in ground-based DOAS observations (Frieß et al., 2005) as well as $\mathrm{ClO}$ observations by MIPAS (von Clarmann et al., 2009) - was only slightly lower than in other Antarctic winters.

PSC maps for the austral winter/spring of the years 2002 to 2008 are shown in Fig. 10 which show that PSCs mainly appear at latitudes poleward of about $58^{\circ} \mathrm{S}$. Furthermore, the PSC occurrence rates are not zonally homogeneous but shifted off the pole towards the South-Atlantic sector. The latitudes where PSCs are detected are in good qualitative agreement with the WACCM CCM results presented by 

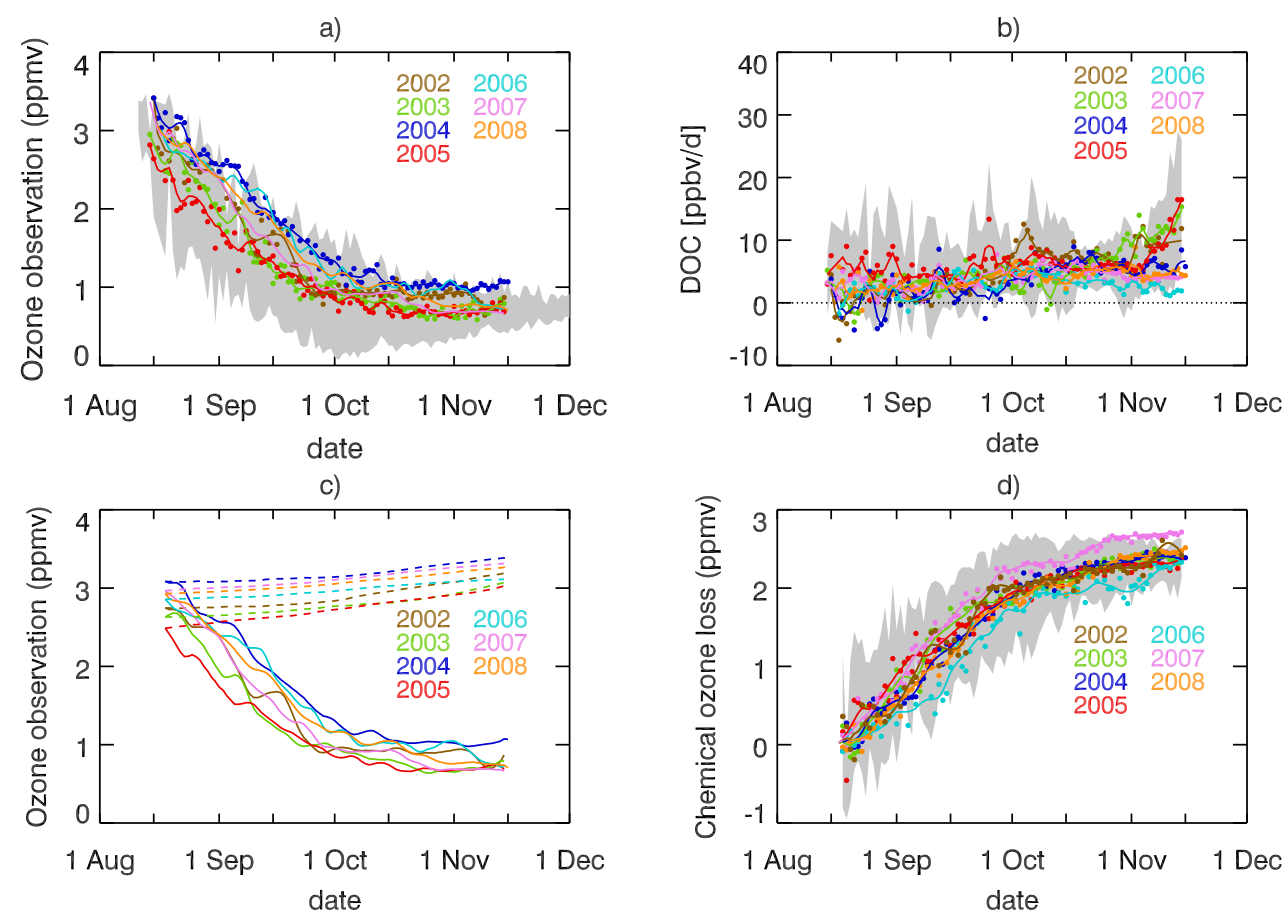

e)

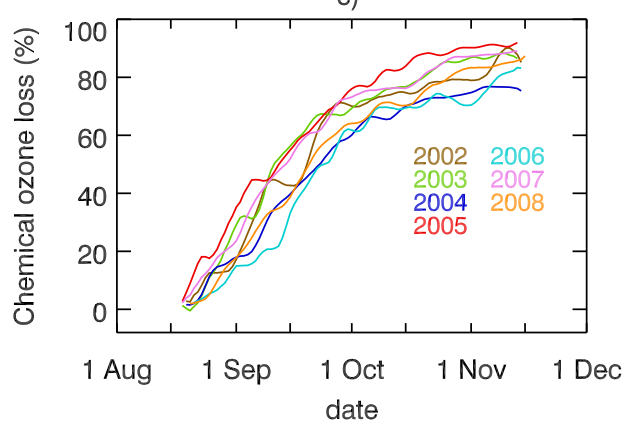

Fig. 9. Chemical ozone loss results for the Antarctic polar vortices 2002 to 2008 at the $475 \mathrm{~K}$ isentropic level. (a) Observed vortex average ozone mixing ratio time series. (b) Daily ozone mixing ratio change (DOC) due to diabatic descent determined with MIDRAD model simulations. (c) Accumulated ozone mixing ratio from daily diabatic descent (dashed lines) and the observed ozone mixing ratio time series (solid lines). (d) Chemical ozone losses in ppmv relative to the mean of the period August 15 - 22 and starting on August 18. (e) Chemical ozone loss in percent relative to the mean of the period August 15-22 of each year and starting on August 18.

Tilmes et al. (2007). Apart from 2002 the differences in September mean PSC occurrence rates over Antarctica for the different years are rather small. The low PSC occurrence rates in September 2002 are mainly a consequence of the major stratospheric warming leading essentially to the disappearance of PSCs within a few days after 22 September (e.g., von Savigny et al., 2005a).

Figure 11 presents contour plots of the Antarctic ozone losses as a function of time and potential temperature - similar to Fig. 5 for the Northern Hemisphere - for the period 18 August to 15 November of each year.

The chemical ozone loss rates inside the vortices are shown in Table 2. Obviously the Antarctic polar vortex is affected by more severe chemical ozone losses compared to the Arctic vortex and is characterized by a rather small inter-annual variability in chemical ozone losses. As shown in Fig. 11, the maximum absolute ozone loss in terms of mixing ratio occurs near the $500 \mathrm{~K}$ isentropic level, but the entire potential temperature range studied is affected by substantial ozone losses, particularly towards the end of the period considered.

According to Fig. 11 the chemical ozone losses inside the vortex in 2002 are similar to those in the other years if only the $475 \mathrm{~K}$ isentropic level is considered. However, the figure also shows that the ozone losses in 2002 cover a larger isentropic range than most of the other years and the overall maximum ozone loss value - occurring near the $550 \mathrm{~K}$ level 

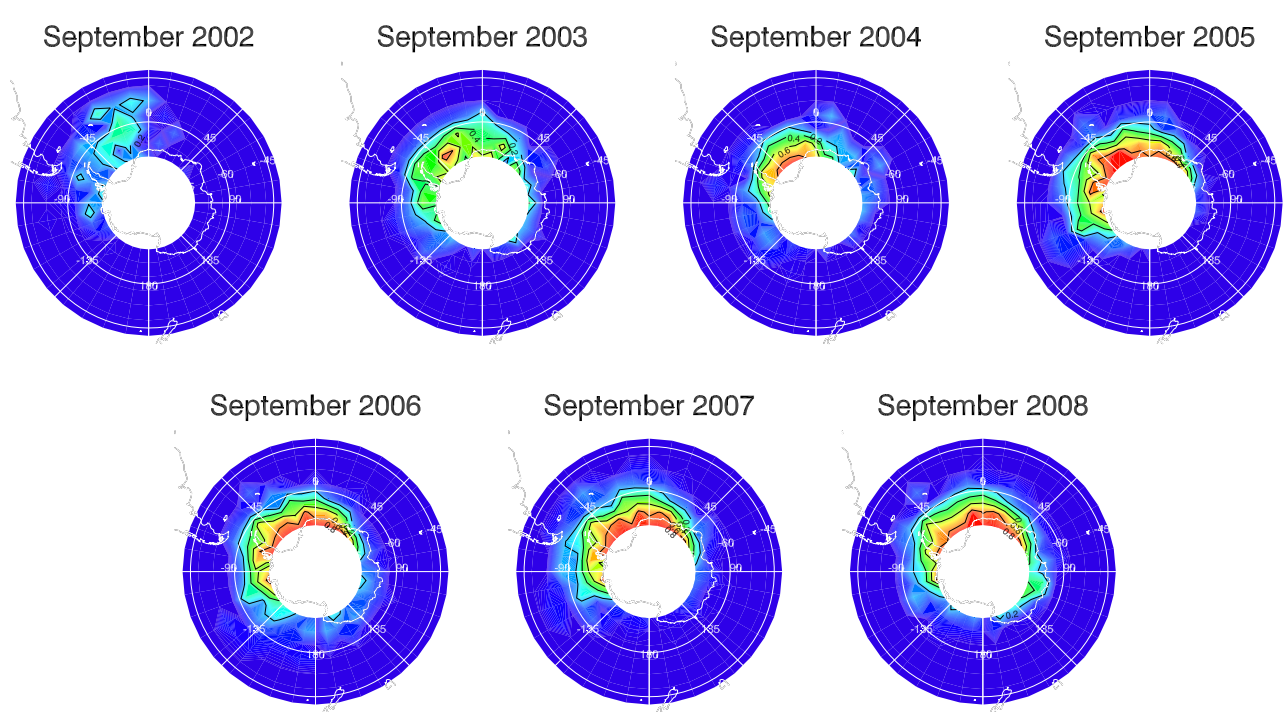

PSC occurrence rate

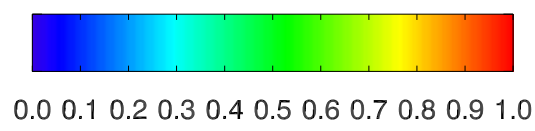

Fig. 10. Maps of PSC occurrence rates in the southern polar atmosphere for September of the years 2002-2008. Contour levels are 0.2, 0.4, 0.6 and 0.8 . Meridians are displayed in steps of $45^{\circ}$ and latitude circles are shown for $45^{\circ} \mathrm{S}$ and $60^{\circ} \mathrm{S}$.

- is larger than for the other years studied. The reasons for this behaviour are currently not known.

As for the Arctic region, the polar vortex volume and the ozone mass loss are also estimated for the Antarctic region. The polar vortex volume between the $450 \mathrm{~K}$ and $600 \mathrm{~K}$ isentropic levels is shown on a daily basis in the left panel of Fig. 12 for the period 15 August to 15 November of each year studied. The volume of the polar vortex is similar for all years with values of $150-300 \times 10^{6} \mathrm{~km}^{3}$ for the period considered except for 2002 when the sudden stratospheric warming occurred around 22 September leading to an abrupt drop of the vortex volume. The ozone mass losses are shown in the right panel of Fig. 12 and reach values of about 50-60 million tons at the end of the season in all years except for 2002, when the values decrease after the end of September. It is worth noting here that the polar vortex was less perturbed at altitudes between 16 and $22 \mathrm{~km}$ than at $26 \mathrm{~km}$ after 22 September 2002 as presented in von Savigny et al. (2005a). The polar vortex volume and ozone mass loss inside the polar vortex still remained relatively high after the September 2002 sudden stratospheric warming.

\section{Comparison of the chemical ozone loss derived from SCIAMACHY measurements to independent observations and models}

In this section the chemical ozone losses in both the Arctic and Antarctic polar vortices are compared with independent techniques and results presented in earlier studies.

\subsection{Arctic winters}

One focus of the comparisons with other data sources and techniques for the Arctic is the winter 2004/2005. This winter was chosen, because it was characterized by an unusually large catalytic ozone loss as documented in numerous studies (e.g., Dufour et al., 2006; Grooß and Müller, 2007; Singleton et al., 2007, 2005; Rösevall et al., 2008; Rex et al., 2006). Comparison with previous studies for the other winters will be described later in this section.

\subsubsection{Winter 2004/2005}

Based on data from Rex et al. (2006) the vertical variation of the chemical ozone losses in terms of mixing ratio versus potential temperature for the time period from 5 January to 25 March 2005 and derived from measurements with different instruments is presented in Fig. 13. The red solid circles show the corresponding ozone loss derived from SCIAMACHY observations using the vortex average approach described above also for the period 5 January to 25 March 2005 as in 

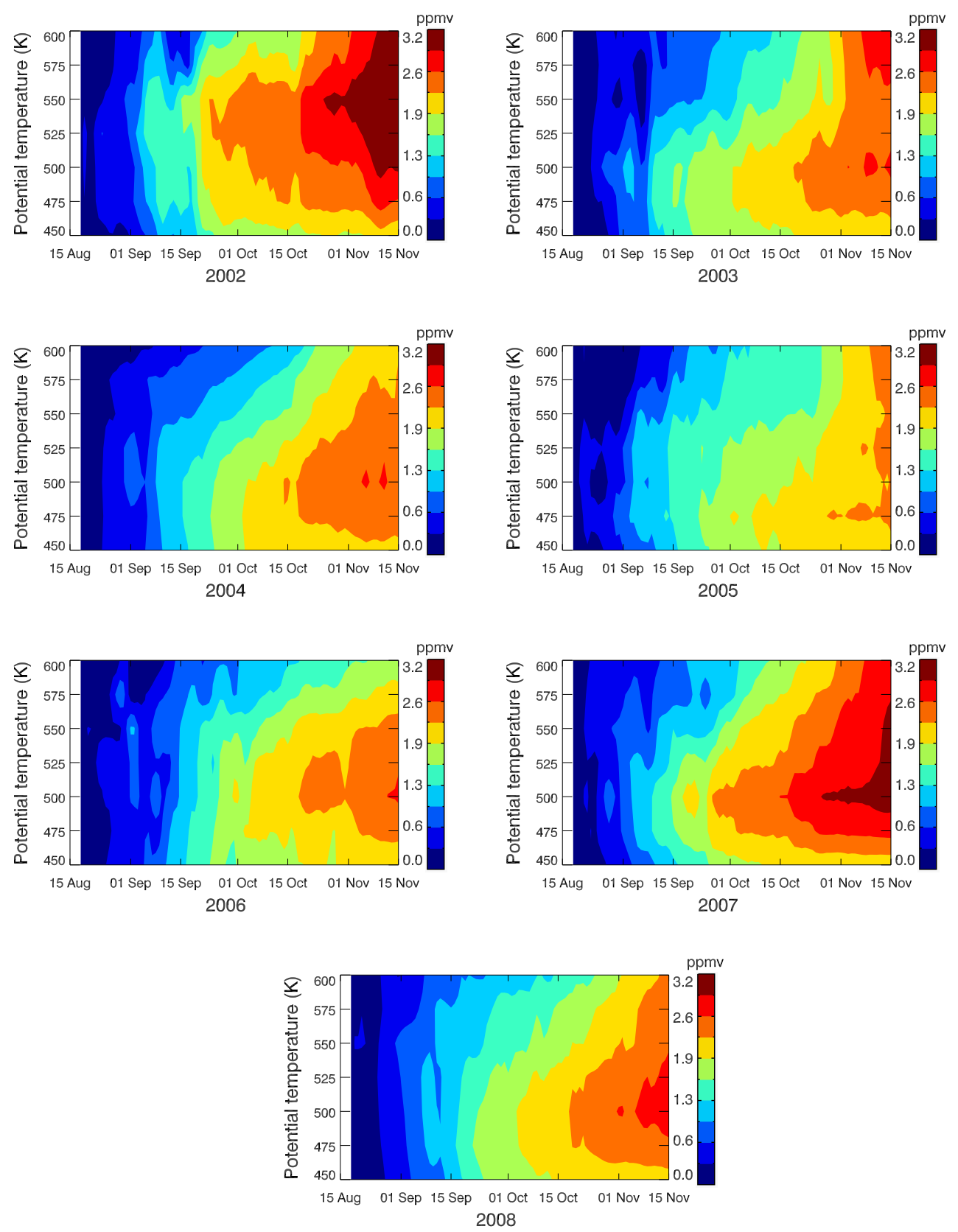

Fig. 11. Derived vortex average ozone losses as a function of time and potential temperature between the $450 \mathrm{~K}$ and $600 \mathrm{~K}$ isentropic levels in the Antarctic winter stratosphere for the years 2002 to 2008. The period August $15-22$ was used as the reference period for the derivation of the chemical ozone losses and the ozone losses are determined starting on August 18 of each year.

Rex et al. (2006). Note, that no SCIAMACHY data below the $425 \mathrm{~K}$ isentropic level is presented here, because SCIAMACHY did not sample the vortex below this level during the first half of January, according to the vortex criterion. The error bars represent standard deviations based on error propagation of the standard deviations of the observed mean vortex ozone and the estimated diabatic ozone change. The green, black and orange lines are based on POAM II/III, SAGE III and ozonesonde measurements, respectively. The dark-blue line is also taken from Rex et al. (2006) and is based on the Match method. The results of this winter were also compared with simulations of the Chemical Lagrangian Model of the Stratosphere (CLaMS) from an update of Grooß and Müller (2007). This update includes an improved initialization of chlorine partitioning after ACE-FTS, an updated parameterization of heterogeneous chemistry (Shi et al., 2001) and absorption cross sections for $\mathrm{Cl}_{2} \mathrm{O}_{2}$ given by the von Hobe et al. (2009) matrix spectrum measurements scaled to 

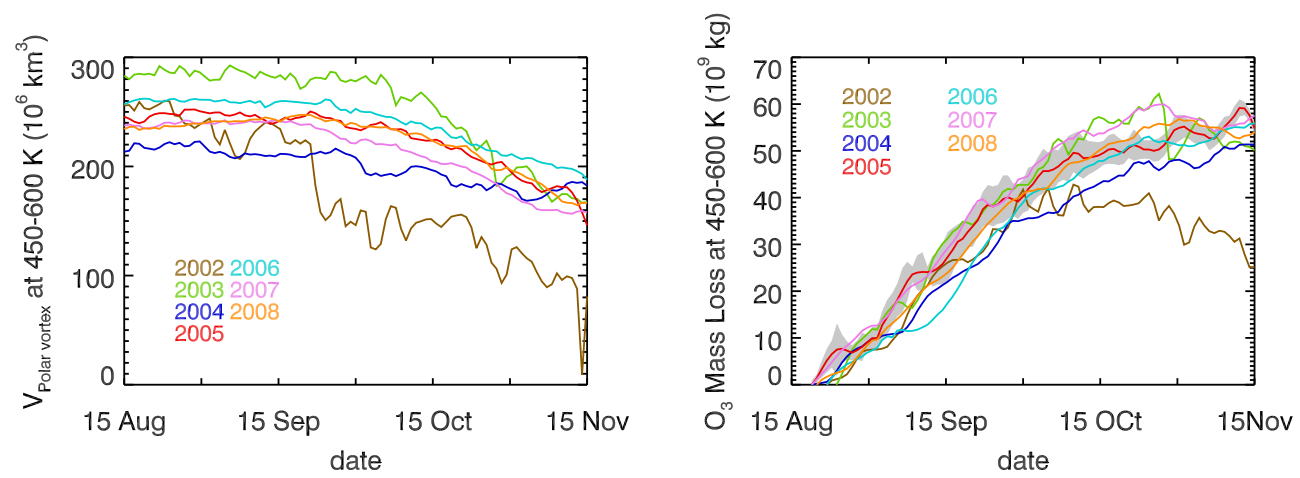

Fig. 12. Time evolution of the polar vortex volume (left panel) and the ozone mass loss inside the vortex (right panel) between the $450 \mathrm{~K}$ and $600 \mathrm{~K}$ isentropic levels in the Antarctic winter stratosphere. The ozone losses below the $550 \mathrm{~K}$ level are driven by halogen compounds formed in heterogeneous reactions, while at higher isentropic levels $\mathrm{NO}_{\mathrm{x}}$ driven ozone losses may become important near the end of austral spring.

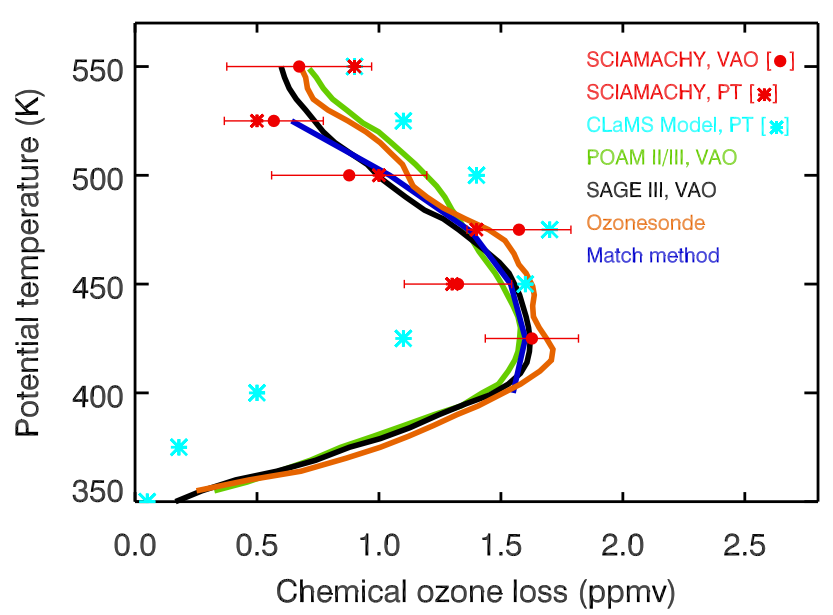

Fig. 13. Comparison of the vertical variation of the chemical ozone loss in the Arctic polar vortex for the time period 5 January-25 March 2005 estimated using various data sources and techniques. The red circles with error bars represent the accumulated ozone loss using a vortex averaged method from this study (denoted by VAO). The cyan asterisks represent the ozone loss derived by subtracting the simulated ozone from the passive ozone tracer (denoted by PT) for the selected SCIAMACHY vortex observation locations. The red asterisks depict passive tracer subtraction between SCIAMACHY observed data and the corresponding CLaMS passive ozone tracer. The POAM, SAGE, ozone sonde as well as the match technique data were taken from Rex et al. (2006).

Chen (2009). The simulation also includes a passive ozone tracer and was initialized on 1 December 2004. As the estimate of vortex average ozone loss critically depends on the choice of the vortex edge, we interpolated the CLaMS simulation to the locations of the selected SCIAMACHY observations. The vortex edge at $450 \mathrm{~K}$ was used in CLAMS also for the selected data points at the levels below $450 \mathrm{~K}$.
Very good agreement is found between the chemical ozone losses derived from SCIAMACHY observations based on the vortex averaging technique (red solid circles in Fig. 13) and the passive tracer subtraction technique (red asterisks in Fig. 13). We note that this close agreement of two entirely different techniques implies that the diabatic descent rates used as part of the vortex average technique are robust and justifies their use in this study.

Above $450 \mathrm{~K}$ the ozone losses derived from SCIAMACHY and CLaMS agree also with the other ozone loss estimates. Below $450 \mathrm{~K}$ CLaMS simulates lower ozone depletion than the other ozone loss estimates. This could be at least partly attributed to the fact that transport of air across the vortex edge is not considered in the other ozone loss estimates. Grooß et al. (2008) showed for the winter 2002/03 that neglecting the transport through the vortex edge causes an over-estimation of ozone loss below about $475 \mathrm{~K}$.

We conclude that the vertical variation of the chemical ozone losses derived from SCIAMACHY ozone profile measurements using a vortex averaged method is in good agreement with other data sources and methods for the Arctic winter 2004/2005. Additionally, the accumulated ozone losses calculated from SCIAMACHY ozone profile data using different methods, i.e., a vortex average technique (red circles in Fig. 13) and the passive subtraction method (red asterisks in Fig. 13) are very consistent.

After this direct comparison of the ozone losses during the Arctic winter 2004/2005 we now compare our results with several other published studies for this winter that mostly differ in the periods investigated. The vertical variation of the chemical ozone losses determined in most of these studies is also depicted in Fig. 14. It is, however, essential to keep in mind that the studied periods may be different. The time period used for the determination of chemical ozone losses from SCIAMACHY observations was chosen to be January 5 to March 10, as in the study of Manney et al. (2006) in order 
to find the best compromise in terms of the time periods of the other studies used in the following comparison.

Manney et al. (2006) examined the chemical ozone loss in the Arctic winter 2004/2005 from 5 January-10 March using Aura/MLS as well as POAM observations (shown as orange and blue squares in Fig. 14). The maximum vortex averaged ozone loss during this period was estimated to be $1.2-1.3$ ppmv around the $450 \mathrm{~K}$ level. As shown in Fig. 14 the Manney et al. (2006) chemical ozone loss values based on Aura/MLS observations are in good agreement with the values based on SCIAMACHY observations except at the $475 \mathrm{~K}$ level. The ozone loss estimates based on POAM observations are systematically lower than the SCIAMACHY and the Aura/MLS values. According to Manney et al. (2006) the difference between the results based on POAM and Aura/MLS observations may be related to differences in sampling of the vortex.

Rösevall et al. (2008) employed measurements with the Aura/MLS and Odin/SMR instruments to infer vortex averaged chemical ozone losses using two independent techniques. The first method - based on the ozone evolution on $\mathrm{N}_{2} \mathrm{O}$ isopleths yields ozone losses of 1.0-1.1 ppmv for Aura/MLS, and 0.7-0.9 ppmv for Odin/SMR measurements, respectively. These values were derived for the 430 $460 \mathrm{~K}$ level and for the period from 1 January to 14 March 2005. The second method based on the DIAMOND assimilation system yielded ozone losses at the $450 \mathrm{~K}$ level of $0.9-1.3$ ppmv derived from Aura/MLS, and values of 0.6$0.9 \mathrm{ppmv}$ derived from Odin/SMR measurements, respectively, again for the period 1 January to 14 March, 2005. These values are also shown as violet and green diamonds in Fig. 14. The Rösevall et al. (2008) ozone loss estimates based on Odin/SMR measurements are significantly lower than the values derived in this and in most other studies. The exact reasons for this underestimation are not well known, but possible reasons are discussed in Rösevall et al. (2008). The values based on the DIAMOND assimilation system and on Aura/MLS measurements are in good agreement with the results based on the vortex average technique applied to SCIAMACHY observations presented here.

Singleton et al. (2007) used the passive subtraction technique to quantify the daily chemical ozone loss using the SLIMCAT model and ozone measurements from the POAM III, SAGE III, EOS MLS, ACE-FTS, and MAESTRO instruments by averaging over the measurement locations inside the vortex during the period from beginning of December 2004 to the end of March 2005 in the Arctic stratosphere. All instruments provided consistent results, with a maximum inferred ozone loss of 2-2.3 ppmv at the $450-475 \mathrm{~K}$ isentropic level, which is significantly larger than the ozone losses estimated in the present study (see panel d of Fig. 4). We note that somewhat larger ozone losses have to be expected for the Singleton et al. (2007) study, because the studied period is considerably longer than in our analysis. Moreover, Singleton et al. (2007) used a passive subtraction method - ex-

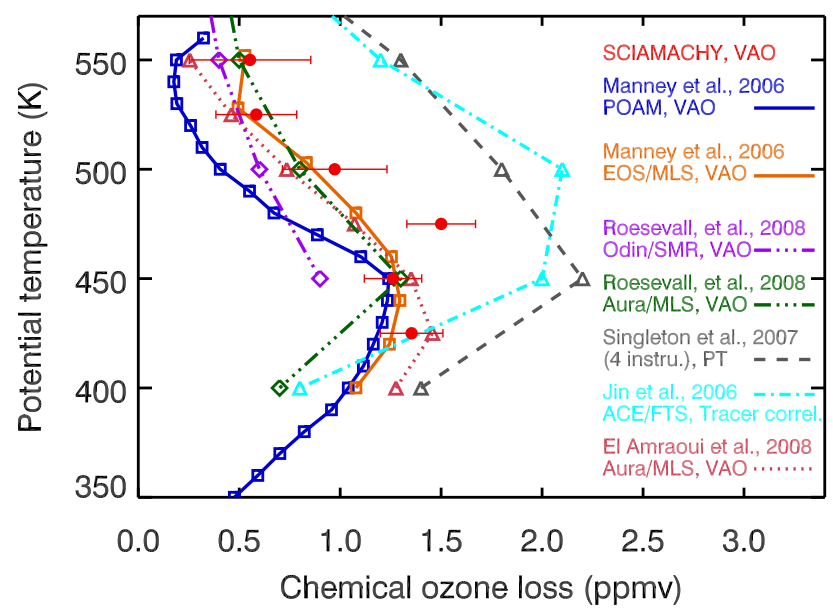

Fig. 14. Comparison of the vertical variation of the chemical ozone loss in the 2004/2005 Arctic polar vortex derived in different studies and based on different time periods. The periods investigated are: 5 January to 10 March for SCIAMACHY and Manney et al. (2006); 1 January to 14 March for Rösevall et al. (2008); December 1 to mid-March for Singleton et al. (2007); 1-7 January to 8-15 March for Jin et al. (2006); January 10 to March 10 for El Amraoui et al. (2008).

cluding all chemical reactions for the passive case - which may also yield larger chemical ozone losses. Grooß and Müller (2007) used CLaMS model simulations to estimate the chemical ozone loss in the same year applying a vortex average method. The ozone loss results from Singleton et al. (2007) and Grooß and Müller (2007) exhibit similar patterns compared to the ozone losses derived from SCIAMACHY limb observations using a vortex average method shown in Fig. 5 , i.e., the ozone loss peaks near the $450 \mathrm{~K}-500 \mathrm{~K}$ isentropic levels. The passive subtraction technique applied by Kuttippurath et al. (2010a) to the Mimosa-Chim simulations and MLS measurements yielded a maximum loss of $\sim 1.5-$ $1.7 \mathrm{ppmv}$ occurring at the $475 \mathrm{~K}$ level. In addition, there is good correspondence of the chemical ozone loss feature at higher isentropic levels in Fig. $5(\sim 575-600 \mathrm{~K}$ at the end of period investigated) with the CLaMS results presented by Grooß and Müller (2007). However, this feature - attributed to $\mathrm{NO}_{\mathrm{x}}$ driven catalytic ozone loss - does neither appear in the multi-instrument analysis of Singleton et al. (2007) compared to 1.5 ppmv observed by SCIAMACHY nor in the purely model-based passive tracer subtraction using the Mimosa-Chim model as described in Kuttippurath et al. (2010a).

Jin et al. (2006) used four different techniques to determine chemical ozone losses during the 2004/2005 winter for the periods of 1-7 January to 8-15 March using ACEFTS observations and found an average maximum ozone loss of about $2.1 \mathrm{ppmv}$ at the $475-500 \mathrm{~K}$ level. The four methods were correlations between ozone and long-lived tracers (yielding $\sim 1.8-2.0 \mathrm{ppmv}$ loss), an artificial tracer 
correlation method ( $\sim 2.1 \mathrm{ppmv}$ loss), a profile descent technique ( $\sim 2.3$ ppmv loss), and a method based on the empirical relationship between ozone loss and potential PSC volume ( $\sim 108$ DU column $\mathrm{O}_{3}$ loss). The Jin et al. (2006) results are depicted as cyan triangles in Fig. 14. Apparently, these ozone losses are significantly larger than the SCIAMACHY values derived in this study, despite the fact that the period considered in Jin et al. (2006) is similar to the one the SCIAMACHY and Manney et al. (2006) results are based on. The high ozone losses derived by Jin et al. (2006) may be a consequence of the reference measurements containing outside vortex air. This is suggested by the study by von Hobe et al. (2006) showing lower ozone mixing ratios at high equivalent latitudes - and similar periods - than presented by Jin et al. (2006). Rösevall et al. (2008) attributed around 0.8 ppmv of the total ozone decline reported by Jin et al. (2006) to the inhomogeneous distribution of ozone inside the vortex and the sampling characteristics of the ACE/FTS solar occultation instrument.

El Amraoui et al. (2008) investigated the ozone loss using a vortex average technique based on assimilated $\mathrm{O}_{3}$ and $\mathrm{N}_{2} \mathrm{O}$ measurements with Aura/MLS. Their work shows a maximum chemical ozone loss of about $1.5 \mathrm{ppmv}$ at the $425 \mathrm{~K}$ level for the period between 10 January and 10 March, 2005. The vertical variation of the ozone loss derived by El Amraoui et al. (2008) is depicted as red triangles in Fig. 14. These values are in good overall agreement with the SCIAMACHY results, except for the $475 \mathrm{~K}$ level where the SCIAMACHY ozone loss value is about 0.4 ppmv larger.

Tsvetkova et al. (2007) inferred the polar ozone loss from SAGE-III observations using a vortex average descent method over the period 1 January-25 March, 2005. The maximum ozone loss was found to be about $1.7 \mathrm{ppmv}$ and occurred at $450-475 \mathrm{~K}$. This value is slightly larger than the SCIAMACHY ozone loss value at $475 \mathrm{~K}$, but is qualitatively consistent with the longer period considered by Tsvetkova et al. (2007).

Jackson and Orsolini (2008) investigated the ozone loss based on an assimilation of Aura/MLS and SBUV/2 ozone profile observations. Their work resulted in a peak ozone loss at the $450 \mathrm{~K}$ level of about $0.6 \mathrm{ppmv}$ for the period from 1 February to 10 March. If the ozone loss during January 2005 is accounted for, then the ozone losses at the $450 \mathrm{~K}$ level between 1 January and mid-March reach $0.8-1.2$ ppmv, in better agreement with the results presented in Fig. 13. Additionally, a secondary ozone loss peak at $650 \mathrm{~K}$ with values reaching about 0.4 ppmv was observed in this study.

We note that the ozone losses for the Arctic winter 2004/2005 determined in other studies and using different methods have also been summarized by Kuttippurath et al. (2010a) and Feng et al. (2011).

The main conclusion of this section is that the chemical ozone losses derived from SCIAMACHY ozone profile measurements for the 2004/2005 winter roughly fall in the mid- dle of the results published in earlier studies on this Arctic winter.

\subsubsection{Other cold Arctic winters: 2002/2003, 2006/2007, and 2007/2008}

We now compare our results for the Arctic winter 2002/2003 with results published in the literature. Our estimate of the accumulated ozone loss inside the polar vortex between 22 January-16 April 2003 is 0.44 ppmv at the level. For the period from the beginning until the end of February an ozone loss of about 0.38 ppmv is derived at this $475 \mathrm{~K}$ level. Christensen et al. (2005) used Match and vortex average methods to derive the accumulated ozone loss at the $479 \mathrm{~K}$ isentropic level between 10 December-10 March of about $1.6 \mathrm{ppmv}$ and $1.0 \mathrm{ppmv}$, respectively. Singleton et al. (2005) found accumulated ozone losses of about $1.0 \mathrm{ppmv}$ at the $475 \mathrm{~K}$ isentropic level between 1 December-15 March. Tilmes et al. (2004) derived accumulated ozone losses of about $1.4 \mathrm{ppmv}$ in the $410-465 \mathrm{~K}$ isentrope range from the beginning until the end of February 2003 based on the tracer correlation method using HALOE observations of $\mathrm{HF}$ and $\mathrm{CH}_{4}$. Streibel et al. (2006) determined the accumulated ozone loss for the period 1 December-16 March and obtained about $1.6 \mathrm{ppmv}$ at the $475 \mathrm{~K}$ isentropic level using the Match technique.

At a first glance the accumulated chemical ozone loss at the $475 \mathrm{~K}$ for the $2002 / 2003$ winter determined in our study appears to be systematically lower than the values determined in the other studies. However, this is partly expected because the period considered in our study only started in mid-January (see Table 1), when temperatures increased afterwards and the vortex split as discussed in Tilmes et al. (2004). The investigated periods in most of the other studies started much earlier than in our study.

Rösevall et al. (2007a) assimilated Odin/SMR ozone profile measurements using a 2-D isentropic transport model from January to May of the winters 2002/2003, 2004/2005, and 2006/2007 for equivalent latitudes north of $65^{\circ} \mathrm{N}$ and $72^{\circ} \mathrm{N}$. Their ozone loss determination yielded more or less similar values of the chemical ozone losses of about $0.7 \mathrm{ppmv}$ for all three winters and for the period starting at the beginning of January until the end of March at the $475 \mathrm{~K}$ isentropic level (see Fig. 6 in Rösevall et al. (2007a)). In Fig. 15 we compare the chemical ozone losses for the winters 2002/2003, 2004/2005, and 2006/2007 derived in Rösevall et al. (2007a) with the SCIAMACHY results presented here. The period for all ozone loss values shown in Fig. 15 is 22 January to 31 March. The Rösevall et al. (2007a) values are taken from their Fig. 6. At the $575 \mathrm{~K}$ level the agreement between the Rösevall et al. (2007a) ozone loss estimates and the values derived in this study is good for the winters 2002/2003 and $2006 / 2007$. At the $475 \mathrm{~K}$ and $525 \mathrm{~K}$ levels and for the winters 2004/2005 and 2006/2007 the ozone losses found by Rösevall et al. (2007a) are systematically lower than the ones determined in this study and also lower than in most other 


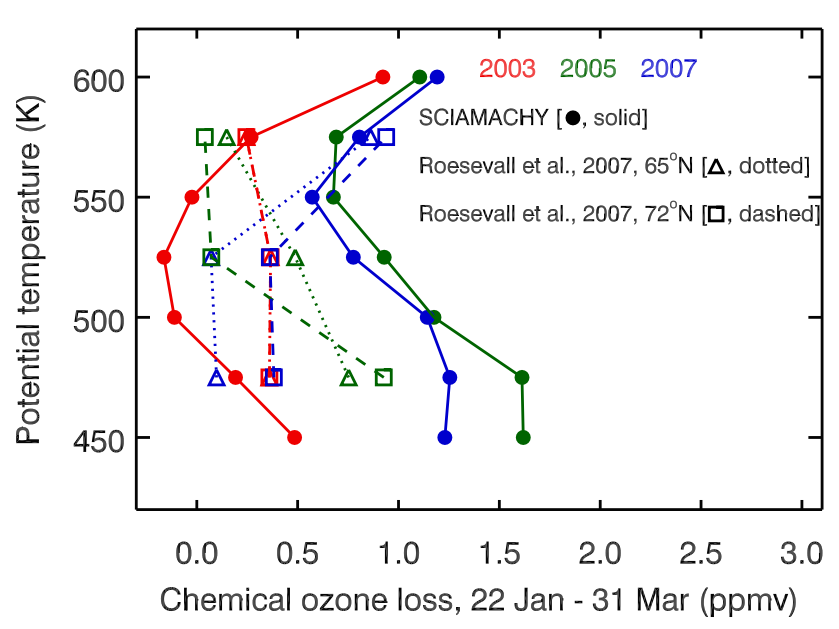

Fig. 15. Comparison of the vertical variation of chemical ozone losses in the Arctic polar vortex derived in this study and by Rösevall et al. (2007a) (their Fig. 6) for the winters 2002/2003, $2004 / 2005$ and $2006 / 2007$. The ozone losses are shown for the period from January 22 to March 31 .

studies. The reasons for these discrepancies are not fully established, but are likely related to different sampling of the vortex and the fact that Rösevall et al. (2007a) considered only locations poleward of $72^{\circ}$ equivalent latitude.

Winter 2006/2007 exhibits a continuous increase of accumulated ozone losses until the end of April at the 525$575 \mathrm{~K}$ isentropic levels (see Fig. 5), which is in good qualitative agreement with the results presented in Fig. 6 of Rösevall et al. (2007a). However, the absolute ozone losses determined in this study are systematically larger than the Rösevall et al. (2007a) results.

Kuttippurath et al. (2010a) have studied the accumulated chemical ozone losses for the Arctic winters 2004/2005 to 2009/2010 and the period from the beginning of December to the end of March applying the passive tracer technique to Mimosa-Chim simulations and MLS measurements (see Fig. 4 in Kuttippurath et al. (2010a)). Our accumulated chemical ozone loss results shown in Fig. 5 clearly exhibit similar patterns and similar values for the winters 2004/2005, $2006 / 2007$ and 2008/2009. Comparatively large losses were found for the winters 2006/2007 and 2007/2008 by Kuttippurath et al. (2010a) and in this study. For the 2006/2007 winter, the ozone loss derived by Kuttippurath et al. (2010a) shows a double peak feature with maximum ozone losses of about 1.3 ppmv at both the $500 \mathrm{~K}$ and the $675 \mathrm{~K}$ isentropic levels. A similar feature is also present in our results (See Fig. 5) with a double peak in chemical ozone losses at the end of March at $500 \mathrm{~K}$ and $600 \mathrm{~K}$ with ozone losses of about 2 ppmv and 1.6 ppmv, respectively. However, Kuttippurath et al. (2010a) found the ozone losses during the winter 2007/2008 to be larger than for $2006 / 2007$, whereas our study shows the opposite.



Fig. 16. Time series of seasonally accumulated (between the start day as shown in Table 1 and 1 April) vortex average chemical ozone loss at the $475 \mathrm{~K}$ isentropic level and PSC occurrence rate for the months of January and February and the $50^{\circ}-65^{\circ} \mathrm{N}$ latitude range. $\mathrm{W}$ and $\mathrm{E}$ indicate the westerly and easterly phases of the QBO. The open circles for the years 2006 and 2009 show the calculated chemical ozone loss up to a date well before 1 April.

\subsubsection{Warm Arctic winters: 2003/2004, 2005/2006 and 2008/2009}

The 2003/2004 and 2005/2006 winters were characterized by the occurrence of major mid-winter stratospheric warmings. For the winter 2003/2004 we essentially found no chemical ozone losses from January to April at the $475 \mathrm{~K}$ isentropic level, but significant ozone losses near the $600 \mathrm{~K}$ level in late March and April (Fig. 5). This feature is in good agreement with the results presented by Feng et al. (2005). They found low accumulated ozone loss of about $0.6 \mathrm{ppmv}$ at the $460 \mathrm{~K}$ level for winter 2003/2004 between 1 December and 30 March using SLIMCAT 3-D CTM as well as larger ozone losses at about $620 \mathrm{~K}$ potential temperature.

Short periods of relatively minor ozone losses during winters 2005/2006 and 2008/2009 were reported by Kuttippurath et al. (2010a) and Manney et al. (2009), in agreement with our results. Manney et al. (2009) found that during the 2008/2009 winter the $\mathrm{N}_{2} \mathrm{O}$ descent in December was stronger, and the wind reversal to easterlies happened more rapidly than for the winter 2006/2007. Furthermore, the reestablishment of the westerly flow occurred more slowly in 2008/2009 compared to 2006/2007. The 2009 SSW had a more profound impact on the lower stratosphere than any previously observed SSW.

Summarizing, we note that the ozone losses determined for the Arctic winters investigated in our study are in good general agreement with most previous studies. The existing differences may be due to the following reasons: (1) SCIAMACHY limb scatter observations do not allow sampling the entire vortex - particularly in January only the edge of 
the vortex is sampled; (2) The differences in reference dates complicate the quantitative comparison of our results with previously published results; (3) Mixing across the vortex boundary is neglected; (4) Uncertainties in the calculated diabatic descent rates.

\subsubsection{Effect of the QBO}

In Fig. 16 we show the accumulated Arctic chemical ozone loss the at $475 \mathrm{~K}$ isentropic level by 1 April of each year (black line), together with the PSC occurrence rates for the months of January and February and for the $50^{\circ}-65^{\circ} \mathrm{N}$ latitude range (red line). The letters $\mathrm{E}$ and $\mathrm{W}$ indicate the easterly/westerly phase of the QBO (e.g., Baldwin et al., 2001; Labitzke and Kunze, 2009). This depiction now suggests with the exception of the unusual winter 2008/2009 (Labitzke and Kunze, 2009) - a dependence of the relative magnitude of both the chemical ozone loss and the PSC occurrence rate on the phase of the QBO. The QBO westerly phase appears to be associated with large PSC occurrence and ozone losses, and the easterly phase with lower PSC occurrence rates. This is consistent with the Holton-Tan mechanism (Holton and Tan, 1980) that relates the westerly phase of the QBO with a more stable and colder Arctic vortex, subsequently leading to higher PSC occurrence and larger chemical ozone destruction.

According to Labitzke (1987) and Labitzke and van Loon (1988), the dependence of the stability of the vortex and the temperatures in the lower polar stratosphere is more obvious during solar minimum conditions. The declining phase of solar cycle 23 was characterized by an unusually extended solar minimum lasting from 2005-2009, and even in 2004 solar activity proxies show that solar activity was already quite low. Therefore, the alternating pattern of cold and warm Arctic winters observed in Fig. 16 mainly coincides with solar minimum conditions, making the QBO signature consistent with the works by, e.g., Labitzke (1987), Labitzke and van Loon (1988) and Camp and Tung (2007) - if the winter 2008/2009 is ignored. The exceptional winter 2008/2009 contradicts the expectation, because solar activity was still low and the QBO was in its westerly phase. As described in Labitzke and Kunze (2009), this behavior is anomalous and is attributed to yet unexplained internal variability of the atmosphere.

\subsection{Antarctic winters}

The chemical ozone losses during Antarctic winters have been discussed in many previous studies. In general, the ozone losses in the Antarctic polar vortex do not exhibit the strong inter-annual variability typical for the Arctic winters. Ozone depletion in the Antarctic vortex typically starts between early July and mid-August and slows down during the last week of September (e.g., Tilmes et al., 2006; Kuttippurath et al., 2010b). The decrease in the ozone loss rates is due to the fact that ozone has already been almost completely destroyed in a certain isentrope range. This time evolution in relative ozone losses has been presented, e.g., in a series of scientific assessments of ozone depletion by WMO, by Kuttippurath et al. (2010b) using the passive subtraction method, by Tilmes et al. (2006) using ILAS satellite observations and is also seen in Fig. 9 of our study.

For a quantitative comparison of chemical ozone losses during Antarctic winter, we select the winter 2003 - also investigated by Tilmes et al. (2006) and Rösevall et al. (2007b). The accumulated chemical ozone losses using tracer-tracer correlations based on ILAS-II observations determined in the study of Tilmes et al. (2006) (Fig. 8) during the period from mid-August to mid-October 2003 amount to about 2.0, 1.3 and 0.5 ppmv for the $430 \mathrm{~K}-470 \mathrm{~K}, 520 \mathrm{~K}-560 \mathrm{~K}$ and $580 \mathrm{~K}-$ $620 \mathrm{~K}$ isentropic ranges, respectively. Our analysis resulted in accumulated ozone losses of about 2.3, 1.8 and $0.8 \mathrm{ppmv}$ for the same isentrope ranges and over the same period. Tilmes et al. (2006) also mentioned the insignificant interannual variability in ozone losses above $550 \mathrm{~K}$ which is in good agreement with the results presented here. Furthermore, it is also worth mentioning that there is no indication for a double peak structure in ozone losses with a second peak near $600 \mathrm{~K}$ potential temperature - in contrast to the Arctic winters. The second peak near $600 \mathrm{~K}$ might be missing in the Antarctic winters, because of the larger vertical extent of PSC induced ozone loss (see Fig. 11), reaching altitudes where $\mathrm{NO}_{\mathrm{x}}$ chemistry becomes important in spring.

Rösevall et al. (2007b) derived vortex averaged chemical ozone losses at the $475 \mathrm{~K}$ level from 1 August to midOctober, 2003 in the range of $70-90 \%$ and $50-70 \%$, using ozone profile measurements by the Envisat/MIPAS and Odin/SMR satellite instruments, respectively. The ozone losses derived in this study are in good agreement with the Envisat/MIPAS results, but are larger than the Odin/SMR losses presented by Rösevall et al. (2007b).

\section{Conclusions}

In this study a polar vortex average technique was used for estimating ozone losses due to catalytic ozone destruction in the Arctic and Antarctic polar vortices using SCIAMACHY ozone profile observations between 2002 and 2009. The deduced polar ozone losses show distinct interhemispheric differences. The losses in the Arctic polar vortex vary strongly from year to year, while the (absolute in ppmv as well as relative) losses inside the Antarctic vortex were similar for the different years, even in the anomalous year 2002 characterized by the unusually early major stratospheric warming causing the well-documented split vortex. Large ozone losses in the Arctic lower stratosphere were only found to occur during the cold winters 2004/2005 and 2006/2007. The longest depletion period occurred in the 2006/2007 winter. The highest seasonally averaged depletion rate at the $475 \mathrm{~K}$ isentropic 
level of about 24 ppbv per day occurred in the 2004/2005 winter, corresponding to a total relative ozone loss of about $40 \%$ during the studied period and a loss of about $1 \mathrm{ppmv}$ during the month of February. Significant accumulated depletions around 1.4-1.7 ppmv were observed in the lower stratosphere between the $450 \mathrm{~K}$ and $525 \mathrm{~K}$ isentropic levels in March 2005 and March 2007 for periods starting on January 22 of each year. A second ozone loss peak is detected at the end of season near the $600 \mathrm{~K}$ level. The estimated total ozone mass loss inside the Arctic polar vortex between the $450 \mathrm{~K}$ and $600 \mathrm{~K}$ isentropic levels is about 25 million tons for the winter 2004/2005. Much lower ozone mass losses were determined for the warmer winters 2002/2003, 2003/2004, 2005/2006 and 2008/2009.

Large ozone losses inside the Antarctic polar vortex were found every year with similar seasonally averaged ozone loss rates of about 26-31 ppbv per day at the $475 \mathrm{~K}$ level for the period between mid-August and mid-November. The daily loss rates were large from August to late September, and then decreased slowly until mid-November. By that time a total relative ozone loss of about $80-90 \%$ or 2.5 ppmv inside the polar vortex at the $475 \mathrm{~K}$ level occurred regularly each season. Unlike the Arctic vortex the Antarctic vortex does not show evidence for a second ozone loss maximum near $600 \mathrm{~K}$. The total ozone mass loss inside the Antarctic polar vortex is about 50-60 million tons between the $450 \mathrm{~K}$ and $600 \mathrm{~K}$ isentropic levels for all winters, except of winter 2002. For this winter an ozone mass loss by the end of October of about 40 million tons was estimated.

The larger ozone losses observed in the Antarctic winter stratosphere are consistent with low temperatures dominating the polar vortex over a longer period and with higher stability as compared to the Arctic stratosphere. The inter-annual variability in PSC occurrence rate and chemical ozone losses in the Arctic polar vortex is consistent with the known statistical dependence of vortex stability on the phase of the QBO for solar minimum conditions.

The vertical variation of the chemical ozone losses determined from SCIAMACHY limb observations using a vortex average method for the 2004/2005 Northern Hemisphere winter was shown to be consistent with the range of results published in earlier studies. Also for other years, when comparisons were possible consistency between results based on SCIAMACHY measurements and other studies was found. This indicates that the vortex averaging technique used in this study - not allowing to sample the entire vortex at all times - is a valuable and accurate method to study chemical ozone losses in both the Arctic and Antarctic vortices.

Acknowledgements. This work was supported by the German Ministry of Education and Research (BMBF), the German aerospace center (DLR), the University of Bremen, Germany. This study is also a contribution to the DFG SHARP research group. SCIAMACHY is jointly funded by Germany, the Netherlands and Belgium. T. S. would like to thank Lampang Rajabhat University,
Thailand, for the funding support. The authors thank S. Tilmes, $\mathrm{S}$. Solomon and an anonymous reviewer for very helpful comments and suggestions.

Edited by: R. Müller

\section{References}

Baldwin, M. P., Gray, L. J., Dunkerton, T. J., Hamilton, K., Haynes, P. H., Randel, W. J., Holton, J. R., Alexander, M. J., Hirota, I., Horinouchi, T., Jones, D. B. A., Kinnersley, J. S., Marquardt, C., Sato, K., and Takahashi, M.: The quasibiennial oscillation, Rev. Geophys., 39, 179-229, 2001.

Baldwin, M., P., Hirooka, T., O’Neill, A., and Yoden, S.: Major stratospheric warming in the southern hemisphere in 2002: Dynamical aspects of the ozone hole split, SPARC newsletter, No. 20, SPARC Office, Toronto, ON, Canada, 24-26, 2003.

Becker, G., Müller, R., McKenna, D. S., Rex, M., Carslaw, K., and Oelhaf, H.: Ozone loss rates in the Arctic stratosphere in the winter 1994/1995: Model simulations underestimate results of the Match analysis, J. Geophys. Res., 105, 15175-15184, 2000.

Bodeker, G. E., Shiona, H., and Eskes, H.: Indicators of Antarctic ozone depletion, Atmos. Chem. Phys., 5, 2603-2615, doi:10.5194/acp-5-2603-2005, 2005.

Bovensmann, H., Burrows, J. P., Buchwitz, M., Frerick, J., Noël, S., Rozanov, V. V., Chance, K. V., and Goede, A. P. H.: SCIAMACHY: Mission objectives and measurement modes, J. Atmos. Sci., 56, 127-150, 1999.

Braathen, G. O., Rummkainen, M., Kyrö, E., Schmidt, U., Dahlback, A., Jorgensen, T. S., Fabian, R., Rudagov, V. V., Gil, M., and Borchers, R.: Temporal development of ozone within the Arctic vortex during the winter of 1991/1992, Geophys. Res. Lett., 21, 1407-1410, 1994.

Brewer, A. W.: Evidence for a world circulation provided by the measurements of helium and water vapour distribution in the stratosphere, Q. J. Roy. Meteor. Soc., 75, 351-363, doi:10.1002/qj.49707532603, 1949.

Burrows, J. P., Hölzle, E., Goede, A. P. H., Visser, H., and Fricke, W.: SCIAMACHY - Scanning Imaging Absorption Spectrometer for Atmospheric Chartography, Acta Astronautica, 35, 7, 445-451, 1995.

Camp, C. D. and Tung, K.-K.: The influence of the solar cycle and QBO on the late-winter stratospheric polar vortex, J. Atmos. Sci, 64, 1267-1283, 2007.

Chen, H. Y., Lien, C. Y., Lin, W. Y., Lee, Y. T., and Lin, J. J.: UV absorption cross sections of $\mathrm{ClOOCl}$ are consistent with ozone degradation models, Science, 324, 781-784, doi:10.1126/science.1171305, 2009.

Chipperfield, M. P., Lee, A. M., and Pyle, J. A.: Model calculations of ozone depletion in the Arctic polar vortex for 1991/92 to 1994/95, Geophys. Res. Lett., 23, 559-562, 1996.

Christensen, T., Knudsen, B. M., Streibel, M., Andersen, S. B., Benesova, A., Braathen, G., Claude, H., Davies, J., De Backer, H., Dier, H., Dorokhov, V., Gerding, M., Gil, M., Henchoz, B., Kelder, H., Kivi, R., Kyrö, E., Litynska, Z., Moore, D., Peters, G., Skrivankova, P., Stübi, R., Turunen, T., Vaughan, G., Viatte, P., Vik, A. F., von der Gathen, P., and Zaitcev, I.: Vortex-averaged Arctic ozone depletion in the winter 2002/2003, Atmos. Chem. Phys., 5, 131-138, doi:10.5194/acp-5-131-2005, 2005. 
National Weather Service, Climate Prediction Center: Stratosphere: Global temperature time series, available at: http://www. cpc.noaa.gov/products/stratosphere/temperature/, (last access: 2 February 2013), 2009.

Deniel, C., Bevilaqua, R. M., Pommereau, J. P., and Lefèvre, F.: Arctic chemical ozone depletion during the 1994/1995 winter deduced from POAM II satellite observations and the REPROBUS three-dimensional model, J. Geophys. Res., 103, 19231-19244, 1998.

Dobson, G. M. B., Kimball, H. H., and Kidson, E.: Observations of the amount of ozone in the Earth's atmosphere, and its relation to other geophysical conditions. Part IV, Proc. R. Soc. Lond. A, 129, 411-433, 1930.

Dufour, G., Nassar, R., Boone, C. D., Skelton, R., Walker, K. A., Bernath, P. F., Rinsland, C. P., Semeniuk, K., Jin, J. J., McConnell, J. C., and Manney, G. L.: Partitioning between the inorganic chlorine reservoirs $\mathrm{HCl}$ and $\mathrm{ClONO}_{2}$ during the Arctic winter 2005 from the ACE-FTS, Atmos. Chem. Phys., 6, 23552366, doi:10.5194/acp-6-2355-2006, 2006.

Eichmann, K.-U., Weber, M., Bramstedt, K., and Burrows, J. P.: Ozone depletion in the NH winter/spring 1999/2000 as measured by GOME on ERS-2, J. Geophys. Res., 107, 8280, doi:10.1029/2001JD001148, 2002.

El Amraoui, L., Semane, N., Peuch, V.-H., and Santee M. L.: Investigation of dynamical processes in the polar stratospheric vortex during the unusually cold winter 2004/2005, Geophys. Res. Lett., 35, L03803, doi:10.1029/2007GL031251, 2008.

EU: European research in the stratosphere 1996-2000, chap. 3.5, 112-117, EUR 19867, Brussels, 2001.

Farman, J. C., Gardiner, B. G., and Shanklin, J. D.: Large losses of total ozone in Antarctica reveal seasonal $\mathrm{ClOx} / \mathrm{NOx}$ interaction, Nature, 315, 207-210, 1985.

Feng, W., Chipperfield, M. P., Davies, S., von der Gathen, P., Kyrö, E., Volk, C. M., Ulanovsky, A., and Belyaev, G.: Large chemical ozone loss in 2004/2005 Arctic winter/spring, Geophys. Res. Lett., 34, L09803, doi:10.1029/2006GL029098, 2007

Feng, W., Chipperfield, M. P., Davies, S., Sen, B., Toon, G., Blavier, J. F., Webster, C. R., Volk, C. M., Ulanovsky, A., Ravegnani, F., von der Gathen, P., Jost, H., Richard, E. C., and Claude, H.: Three-dimensional model study of the Arctic ozone loss in 2002/2003 and comparison with 1999/2000 and 2003/2004, Atmos. Chem. Phys., 5, 139-152, doi:10.5194/acp-5-139-2005, 2005.

Feng, W., Chipperfield, M. P., Davies, S., Mann, G. W., Carslaw, K. S., Dhomse, S., Harvey, L., Randall, C., and Santee, M. L.: Modelling the effect of denitrification on polar ozone depletion for Arctic winter 2004/2005, Atmos. Chem. Phys., 11, 6559-6573, doi:10.5194/acp-11-6559-2011, 2011

Frieß, U., Kreher, K., Johnston, P. V., and Platt, U.: GroundBased DOAS Measurements of Stratospheric Trace Gases at Two Antarctic Stations during the 2002 Ozone Hole Period, J. Atmos. Sci., 62, 765-777, 2005.

Fussen, D. and López-Puertas, M: Summary on upper atmosphere, Atmospheric Science Conference, Barcelona, Spain, 711 September, 2009.

Geer, A. J., Lahoz, W. A., Jackson, D. R., Cariolle, D., and McCormack, J. P.: Evaluation of linear ozone photochemistry parametrizations in a stratosphere-troposphere data assimilation system, Atmos. Chem. Phys., 7, 939-959, doi:10.5194/acp-7-
939-2007, 2007.

Goutail, F., Harris, N. R. P., Kilbane-Dawe, I., and Amanatidis, G. T.: Ozone loss: the global picture, Proc. European Ozone Meeting, Schliersee, Germany, 1997.

Goutail, F., Pommereau, J.-P., Lefèvre, F., van Roozendael, M., Andersen, S. B., Kåstad Høiskar, B.-A., Dorokhov, V., Kyrö, E., Chipperfield, M. P., and Feng, W.: Early unusual ozone loss during the Arctic winter 2002/2003 compared to other winters, Atmos. Chem. Phys., 5, 665-677, doi:10.5194/acp-5-665-2005, 2005.

Grooß, J.-U. and Müller, R.: The impact of mid-latitude intrusions into the polar vortex on ozone loss estimates, Atmos. Chem. Phys., 3, 395-402, doi:10.5194/acp-3-395-2003, 2003.

Grooß, J.-U., Günther, G., Müller, R., Konopka, P., Bausch, S., Schlager, H., Voigt, C., Volk, C. M., and Toon, G. C.: Simulation of denitrification and ozone loss for the Arctic winter 2002/2003, Atmos. Chem. Phys., 5, 1437-1448, doi:10.5194/acp-5-14372005, 2005.

Grooß, J.-U. and Müller, R.: Simulation of ozone loss in Arctic winter 2004/2005, Geophys. Res. Lett., 34, L05804, doi:10.1029/2006GL028901, 2007.

Grooß, J.-U., Müller, R., Konopka, P., Steinhorst, H.-M., Engel, A., Möbius, T., and Volk, C. M.: The impact of transport across the polar vortex edge on Match ozone loss estimates, Atmos. Chem. Phys., 8, 565-578, doi:10.5194/acp-8-565-2008, 2008.

Guirlet, M., Chipperfield, M. P., Pyle, J. A., Goutail, F., Pommereau, J. P., and Kyrö, E.: Modeled Arctic ozone depletion in winter $1997 / 1998$ and comparison with previous winters, J. Geophys. Res., 105, 22185-22200, 2000.

Harris, N. R. P., Rex, M., Goutail, F., Knudsen, B. M., Manney, G. L., Müller, R., and von der Gathen, P.: Comparison of empirically derived ozone losses in the Arctic vortex, J. Geophys. Res., 107, 8264, doi:10.1029/2001JD000482, 2002.

Haynes, P. H., Marks, C. J., McIntyre, M. E., Shepherd, T. G., and Shine, K. P.: On the "downward control" of extratropical diabatic circulations by eddy-induced mean zonal forces, J. Atmos. Sci., 48, 651-678, 1991.

Holton, J. R. and Tan, H. C.: The influence of the equatorial QBO in the global circulation at 50mb, J. Atmos. Sci., 37, 2200-2208, 1980.

Holton J. R., Haynes, P. H., McIntyre, M. E., Douglass, A. R., Rood, R. B., and Pfister, L.: Stratosphere-troposphere exchange, Rev. Geophys., 33, 403-439, 1995.

Holton, J. R. and Alexander, M. J.: The role of waves in the transport circulation of the middle atmosphere, in: Atmospheric Sciences Across the Stratopause, edited by: Siskind, D. E., Eckermann, S. D., and Summers, M. E., Geophysical Monograph Series No. 123, AGU, 21-35, 2000.

Hoogen, R., Rozanov, V. V., and Burrows, J. P.: Ozone profiles from GOME satellite data: Algorithm description and first validation, J. Geophys. Res., 104, 8263-8280, 1999.

Hoppel, K., Bevilacqua, R., Allen, D., Nedoluha, G., and Randall C.: POAM III observations of the anomalous 2002 Antarctic ozone hole, Geophys. Res. Lett., 30, 1394, doi:10.1029/2003GL016899, 2003.

Hoppel, K. W., Baker, N. L., Coy, L., Eckermann, S. D., McCormack, J. P., Nedoluha, G. E., and Siskind, D. E.: Assimilation of stratospheric and mesospheric temperatures from MLS and SABER into a global NWP model, Atmos. Chem. Phys., 8, 6103- 
6116, doi:10.5194/acp-8-6103-2008, 2008.

IPCC/TEAP: Special report on safeguarding the ozone layer and the global climate system, Cambridge University Press, Cambridge, United Kingdom, New York, USA, 2005.

Jackson, D. R. and Orsolini, Y. J.: Estimation of Arctic ozone loss in winter 2004/05 based on assimilation of EOS MLS and SBUV/2 observations, Q. J. Roy. Meteor. Soc., 134, 1833-1841, 2008.

Jin, J. J., Semeniuk, K., Manney, G.L., Jonsson, A. I., Beagley, S. R., McConnell, J. C., Dufour, G., Nassar, R., Walker, K. A., Boone, C. D., Bernath, P. F, Rinsland, C. P., Urban, J., Murtagh, D., and Petelina, S. V.: Severe Arctic ozone loss in the winter 2004/2005: observations from ACE-FTS, Geophys. Res. Lett., 33, L15801, doi:10.1029/2006GL026752, 2006.

Jones, A., Urban, J., Murtagh, D. P., Eriksson, P., Brohede, S., Haley, C., Degenstein, D., Bourassa, A., von Savigny, C., Sonkaew, T., Rozanov, A., Bovensmann, H., and Burrows, J.: Evolution of stratospheric ozone and water vapour time series studied with satellite measurements, Atmos. Chem. Phys., 9, 6055-6075, doi:10.5194/acp-9-6055-2009, 2009.

Jucks, K. W. and Salawitch, R. J.: Future changes in upper stratospheric ozone, in: atmospheric science across the stratopause, edited by: Siskind, D. E., Eckermann, S. D., and Summers, M. E., Geophys. Mono., 123, AGU, 241-255, 2000.

Knudsen, B. M., Larsen, N., Mikkelsen, I. S., Morcrette, J.-J., Braathen, G. O., Kyrö, E., Fast, H., Gernandt, H., Kanzawa, H., Nakane, H., Dorokhov, V., Yushkov, V., Hansen, G., Gil, M., and Shearman, R. J.: Ozone depletion in and below the Arctic vortex for 1997, Geophys. Res. Lett., 25, 627-630, 1998.

Konopka, P., Grooß, J.-U., Hoppel, K. W., Steinhorst, H.-M., and Müller, R.: Mixing and chemical ozone loss during and after the Antarctic polar vortex major warming in September 2002, J. Atmos. Sci., 62, 848-859, doi:10.1175/JAS-3329.1, 2005.

Konopka, P., Engel, A., Funke, B., Müller, R., Grooß, J.U., Günther, G., Wetter, T., Stiller, G., von Clarmann, T., Glatthor, N., Oelhaf, H., Wetzel, G., López-Puertas, M., Pirre, M., Huret, N., and Riese, M.: Ozone loss driven by nitrogen oxides and triggered by stratospheric warmings can outweigh the effect of halogens, J. Geophys. Res., 112, D5105, doi:10.1029/2006JD007064, 2007.

Kushner, P. L. and Polvani, L. M.: A very large, spontaneous stratospheric sudden warming in a simple AGCM: A prototype for the southern hemisphere warming of 2002?, J. Atmos. Sci., 62, 890897, 2004

Kuttippurath, J., Godin-Beekmann, S., Lefévre, F., and Goutail, F.: Spatial, temporal, and vertical variability of polar stratospheric ozone loss in the Arctic winters 2004/2005-2009/2010, Atmos. Chem. Phys., 10, 9915-9930, doi:10.5194/acp-10-9915-2010, 2010a.

Kuttippurath, J., Goutail, F., Pommereau, J.-P., Lefévre, F., Roscoe, H. K., Pazmino, A., Feng, W., Chipperfield, M. P., and GodinBeekmann, S.: Estimation of Antarctic ozone loss from groundbased total column measurements, Atmos. Chem. Phys., 10, 6569-6581, doi:10.5194/acp-10-6569-2010, 2010b.

Labitzke, K.: Sunspots, the QBO, and the stratospheric temperature in the north polar-region, Geophys. Res. Lett., 14, 535-537, 1987.

Labitzke, K. and van Loon, H.: Associations between the 11-year solar-cycle, the QBO and the atmosphere. Part I: The troposphere and stratosphere in the northern hemisphere in winter, J. Atmos.
Terr. Phys., 50, 197-206, 1988.

Labitzke, K. and Kunze, M.: On the remarkable Arctic winter in 2008/2009, J. Geophys. Res., 114, D00I02, doi:10.1029/2009JD012273, 2009.

Lait, L. R.: An alternative form for potential vorticity, J. Atmos. Sci., 51, 1754-1759, 1994.

Manney, G. L., Krüger, K., Sabutis, J. L., Sena, S. A., and Pawson, S.: The remarkable 2003-2004 winter and other recent warm winters in the Arctic stratosphere since the late 1990s, J. Geophys. Res., 110, D04107, doi:10.1029/2004JD005367, 2005a.

Manney, G. L., Sabutis, J. L., Allen, D. R., Lahoz, W. A., Scaife, A. A., Randall, C. E., Pawson, S., Naujokat, B., and Swinbank, R.: Simulations of dynamics and transport during the September 2002 Antarctic major warming, J. Geophys. Res., 62, 690-707, doi:10.1175/JAS-3313.1, 2005b.

Manney,G. L., Santee, M. L., Froidevaux, L., Hoppel, K., Livesey, N. J., and Waters, J. W.: EOS MLS observations of ozone loss in the 2004-2005 Arctic winter, Geophys. Res. Lett., 33, L04802, doi:10.1029/2005GL024494, 2006.

Manney, G. L., Schwartz, M. J., Krüger, K., Santee, M. L., Pawson, S., Lee, J. N., Daffer, W. H., Fuller, R. A., and Livesey, J.: Aura Microwave Limb Sounder Observations of dynamics and transport during the record-breaking 2009 Arctic stratospheric major warming, Geophys. Res. Lett., 36, L12815, doi:10.1029/2009GL038586, 2009.

Müller, R., and Günther, G.: A generalized form of Lait's modified potential vorticity, J. Atmos. Sci., 60, 2229-2237, 2003.

Nash, E. R., Newman, P. A., Rosenfield, J. E., and Schoeberl, M. R.: An objective determination of the polar vortex using Ertel's potential vorticity, J. Geophys. Res., 101, 9471-9478, 1996.

Newchurch, M. J., Yang, E.-S., Cunnold, D. M., Reinsel, G. C., Zawodny, J. M., and Russell III, J. M.: Evidence for slowdown in stratospheric ozone loss: First stage of ozone recovery, J. Geophys. Res., 108, 4507, doi:10.1029/2003JD003471, 2003.

Newman, P. A. and Nash, E. R.: The unusual southern hemisphere stratosphere winter of 2002, J. Atmos. Sci., 62, 614-628, 2005.

Randel, W. J., Wu, F., Russell III, J. M., Roche, A., and Waters, J. W.: Seasonal cycles and QBO variations in stratospheric $\mathrm{CH}_{4}$ and $\mathrm{H}_{2} \mathrm{O}$ observed in UARS HALOE data, J. Atmos. Sci., 55, 163-185, 1998.

Remsberg, E. E., Marshall, B. T., Garcia-Comas, M., Krueger, D., Lingenfelser, G. S., Martin-Torres, J., Mlynczak, M. G., Russell, J. M., Smith, A. K., Zhao, Y., Brown, C., Gordley, L. L., LopezGonzalez, M. J., Lopez-Puertas, M., She, C.-Y., Taylor, M. J., and Thompson, R. E.: Assessment of the quality of the Version 1.07 temperature-versus-pressure profiles of the middle atmosphere from TIMED/SABER, J. Geophys. Res.-Atmos., 113, D17101, doi:10.1029/2008JD010013, 2008.

Rex, M., von der Gathen, P., Braathen, G. O., Harris, N. R. P., Reimer, E., Beck, A., Alfier, R., Krüger-Carstensen, R., Chipperfield, M., De Backer, H., Balis, D., O'Connor, F., Dier, H., Dorokhov, V., Fast, H., Gamma, A., Gil, M., Kyrö, E., Litynska, Z., Mikkelsen, I. S., Molyneux, M., Murphy, G., Reid, S. J., Rummukainen, M., and Zerefos, D.: Chemical ozone loss in the Arctic winter 1994/1995 as determined by the Match technique, J. Atmos. Chem., 32, 35-59, 1999.

Rex, M., Salawitch, R. J., Harris, N. R. P., von der Gathen, P., Braathen, G. O., Schulz, A., Deckelmann, H., Chipperfield, M., Sinnhuber, B.-M., Reimer, E., Alfier, R., Bevilacqua, R., Hop- 
pel, K., Fromm, M., Lumpe, J., Küllmann, H., Kleinböhl, A., Bremer, H., von König, M., Künzi, K., Toohey, D., Vömel, H., Richard, E., Aikin, K., Jost, H., Greenblatt, J. B., Loewenstein, M., Podolske, J. R., Webster, C. R., Flesch, G. J., Scott, D. C., Herman, R. L., Elkins, J. W., Ray, E. A., Moore, F. L., Hurst, D. F., Romashkin, P., Toon, G. C., Sen, B., Margitan, J. J., Wennberg, P., Neuber, R., Allart, M., Bojkov, B. R., Claude, H., Davies, J., Davies, W., De Backer, H., Dier, H., Dorokhov, V., Fast, H., Kondo, Y., Kyrö, E., Litynska, Z., Mikkelsen, I. S., Molyneux, M. J., Moran, E., Nagai, T., Nakane, H., Parrondo, C., Ravegnani, F., Skrivankova, P., Viatte, P., and Yushkov, V.: Chemical depletion of Arctic ozone in winter 1999/2000, J. Geophys. Res., 107, 8276, doi:10.1029/2001JD000533, 2002.

Rex, M., Salawitch, R. J., Santee, M. L., Waters, J. W., Hoppel, K., and Bevilaqua, R.: On the unexplained stratospheric ozone losses during cold Arctic Januaries, Geophys. Res. Lett., 30, 1008, doi:10.1029/2002GL016008, 2003.

Rex, M., Salawitch, R. J., von der Gathen, P., Harris, N. R. P., Chipperfield, M. P., and Naujokat, B.: Arctic ozone loss and climate change, Geophys. Res. Lett., 31, L04116, doi:10.1029/2003GL018844, 2004.

Rex, M., Salawitch, R. J., Deckelmann, H., von der Gathen, P., Harris, N. R. P., Chipperfield, M. P., Naujokat, B., Reimer, E., Allaart, M., Andersen, S. B., Bevilacqua, R., Braathen, G. O., Claude, H., Davies, J., De Backer, H., Dier, H., Dorokhov, V., Fast, H., Gerding, M., Godin-Beekmann, S., Hoppel, K., Johnson, B., Kyrö, E., Litynska, Z., Moore, D., Nakane, H., Parrondo, M. C., Risley, A. D., Skrivankova, P., Stübi, R., Viatte, P., Yushkov, V., and Zerefos, C.: Arctic winter 2005: Implications for stratospheric ozone loss and climate change, Geophys. Res. Lett., 33, L23808, doi:10.1029/2006GL026731, 2006.

Ricaud, P., Lefèvre, F., Berthet, G., Murtagh, D., Llewellyn, E. J., Mégie, G., Kyrölä, E., Leppelmeier, G. W., Auvinen, H., Boone, C., Brohede, S., Degenstein, D. A., de La Noë, J., Dupuy, E., El Amraoui, L., Eriksson, P., Evans, W. F. J., Frisk, U., Gattinger, R. L., Girod, F., Haley, C. S., Hassinen, S., Hauchecorne, A., Jimenez, C., Kyrö, E., Lautié, N., Le Flochmoën, E., Lloyd, N. D., McConnell, J. C., McDade, I. C., Nordh, L., Olberg, M., Pazmino, A., Petelina, S. V., Sandqvist, A., Seppälä, A., Sioris, C. E., Solheim, B. H., Stegman, J., Strong, K., Taalas, P. Urban, J., von Savigny, C., von Scheele, F., and Witt, G.: Polar vortex evolution during the 2002 Antarctic major warming as observed by the Odin satellite, J. Geophys. Res., 110, D05302, doi:10.1029/2004JD005018, 2005.

Richter, A., Wittrock, F., Weber, M., Beirle, S., Kühl, S., Platt, U., Wagner, T., Wilms-Grabe, W., and Burrows, J. P.: GOME Observations of Stratospheric Trace Gas Distributions during the Splitting Vortex Event in the Antarctic Winter of 2002. Part I: Measurements, J. Atmos. Sci., 62, 778-785, doi:10.1175/JAS3325.1, 2005.

Rosenlof, K. H. and Holton, J. R.: Estimates of the stratospheric residual circulation using the downward control principle, J. Geophys. Res., 98, 10465-10479, 1993.

Rosenlof, K. H.: Seasonal cycle of the residual mean meridional circulation in the stratosphere, J. Geophys. Res., 100, 5173-5191, 1995.

Rösevall, J. D., Murtagh, D. P., and Urban, J.: Ozone depletion in the 2006/2007 Arctic winter, Geophys. Res. Lett., 34, L21809, doi:10.1029/2007GL030620, 2007a.
Rösevall, J. D., Murtagh, D. P., Urban, J., and Jones, A. K.: A study of polar ozone depletion based on sequential assimilation of satellite data from the ENVISAT/MIPAS and Odin/SMR instruments, Atmos. Chem. Phys., 7, 899-911, doi:10.5194/acp-7899-2007, 2007b.

Rösevall, J. D., Murtagh, D. P., Urban, J., Feng, W., Eriksson, P., and Brohede, S.: A study of ozone depletion in the 2004/2005 Arctic winter based on data from Odin/SMR and Aura/MLS, J. Geophys. Res., 113, D13301, doi:10.1029/2007JD009560, 2008.

Rozanov, A., Rozanov, V., Buchwitz, M., Kokhanovsky, A., and Burrows, J. P.: SCIATRAN 2.0 - A new radiative transfer model for geophysical applications in the $175-2400 \mathrm{~nm}$ spectral region, Adv. Space Res., 36, 1015-1019, 2005.

Rozanov, A.: SCIATRAN 2.X: Radiative transfer model and retrieval software package, available at: http://www.iup.physik. uni-bremen.de/sciatran, (last access: 2 February 2013), 2008.

Sathishkumar, S., Sridharan, S., and Jocobi, Ch.: Dynamical response of low-latitude middle atmosphere to major sudden stratospheric warming events, J. Atmos. Sol.-Terr. Phys., 71, 857-865, 2009.

Shi, Q., Jayne, J. T., Kolb, C. E., Worsnop, D. R., and Davidovits, $\mathrm{P}$ :, Kinetic model for reaction of $\mathrm{ClONO}_{2}$ with $\mathrm{H}_{2} \mathrm{O}$ and $\mathrm{HCl}$ and $\mathrm{HOCl}$ with $\mathrm{HCl}$ in sulfuric acid solutions, J. Geophys. Res., 106, 4259-24274, 2001.

Shine, K. P.: On the cause of the relative greenhouse strength of gases such as the halocarbons, J. Atmos. Sci., 48, 1513-1518, 1991.

Singleton, C. S., Randall, C. E., Chipperfield, M. P., Davies, S., Feng, W., Bevilacqua, R. M., Hoppel, K. W., Fromm, M. D., Manney, G. L., and Harvey, V. L.: 2002-2003 Arctic ozone loss deduced from POAM III satellite observations and the SLIMCAT chemical transport model, Atmos. Chem. Phys., 5, 597609, doi:10.5194/acp-5-597-2005, 2005.

Singleton, C. S., Randall, C. E., Harvey, V. L., Chipperfield, M. P., Feng, W., Manney, G. L., Froidevaux, L., Boone, C. D., Bernath, P. F., Walker, K. A., McElroy, C. T. and Hoppel, K. W.: Quantifying Arctic ozone loss during the 2004-2005 winter using satellite observations and a chemical transport model, J. Geophys. Res.Atmos., 112, D7304, doi:10.1029/2006JD007463, 2007.

Sinnhuber, B.-M., Langer, J., Klein, U., Raffalski, U., Künzi, K., and Schrems, O.:, Ground based millimeter-wave observations of Arctic ozone depletion during winter and spring of 1996/97, Geophys. Res. Lett., 25, 3327-3330, 1998.

Siskind, D. E., Froidevaux, L., Russell, J. M., and Lean, J.: Implications of upper stratospheric trace constituent changes observed by HALOE for $\mathrm{O}_{3}$ and $\mathrm{ClO}$ from 1992 to 1995, Geophys. Res. Lett., 25, 3513-3516, 1998.

Solomon, S.: Stratospheric ozone depletion: A review of concepts and history, Rev. Geophys., 37, 275-316, 1999.

Solomon S., Portmann, R. W., Sasaki, T., Hofmann, D. J., and Thompson, D. W. J.: Four decades of ozonesonde measurements over Antarctica, J. Geophys. Res., 110, D21311, doi:10.1029/2005JD005917, 2005.

Solomon, S., Portmann, R. W., and Thompson, D. W. J.: Contrasts between Antarctic and Arctic ozone depletion, P. Natl. Acad. Sci., 104, 445-449, 2007.

Sonkaew, T., Rozanov, V. V., von Savigny, C., Rozanov, A., Bovensmann, H., and Burrows, J. P.: Cloud sensitivity studies for stratospheric and lower mesospheric ozone profile retrievals from mea- 
surements of limb-scattered solar radiation, Atmos. Meas. Tech., 2, 653-678, doi:10.5194/amt-2-653-2009, 2009.

SPARC Report on the Evaluation of Chemistry-Climate Models, V. Eyring, T. G. Shepherd, D. W. Waugh (Eds.), SPARC Report No. 5, WCRP-132, WMO/TD-No. 1526, 2010.

Steinbrecht, W., Claude, H., Schönenborn, F., McDermid, I. S., Leblanc, T., Godin, S., Keckhut, P., van Gijsel, A., Swart, D. P. J., Bodeker, G., Parrish, A., Boyd, I., Kämpfer, N., Hocke, C., Stolarski, R. S., Frith, S. M., Thomason, L. W., Remsberg, E. E., von Savigny, C., Rozanov, A., and Burrows, J. P.: Ozone and temperature trends in the upper stratosphere at five stations of the Network for the Detection of Atmospheric Composition Change, Int. J. Remote Sens., 30, 3875-3886, 2009.

Stolarski, R. S., McPeters, R. D., and Newman, P. A.: The ozone hole of 2002 as measured by TOMS, J. Atmos. Sci., 62(3), 716$720,2005$.

Streibel, M., Rex, M., von der Gathen, P., Lehmann, R., Harris, N. R. P., Braathen, G. O., Reimer, E., Deckelmann, H., Chipperfield, M., Millard, G., Allaart, M., Andersen, S. B., Claude, H., Davies, J., De Backer, H., Dier, H., Dorokov, V., Fast, H., Gerding, M., Kyrö, E., Litynska, Z., Moore, D., Moran, E., Nagai, T., Nakane, H., Parrondo, C., Skrivankova, P., Stübi, R., Vaughan, G., Viatte, P., and Yushkov, V.: Chemical ozone loss in the Arctic winter 2002/2003 determined with Match, Atmos. Chem. Phys., 6, 2783-2792, doi:10.5194/acp-6-2783-2006, 2006.

Swinbank, R. and O'Neill, A.: A stratosphere-troposphere data assimilation system, Mon. Weather Rev., 122, 686-702, 1994.

Tsvetkova, N. D., Yushkov, V. A., Luk'yanov, A. N., Dorokhov, V. M., and Nakane, H.: Record-breaking chemical destruction of ozone in the arctic during the winter of 2004/2005, Izvestiya Atmos. Ocean. Phys., 43, 592-598, 2007.

Tilmes, S., Müller, R, Grooß, J.-U., and Russell, J. M.: Ozone loss and chlorine activation in the Arctic winters 1991-2003 derived with the tracer-tracer correlations, Atmos. Chem. Phys., 4, 21812213, doi:10.5194/acp-4-2181-2004, 2004.

Tilmes, S., Müller, R., Grooß, J.-U., Spang, R., Sugita, T., Nakajima, H., and Sasano, Y.: Chemical ozone loss and related processes in the Antarctic winter 2003 based on Improved Limb Atmospheric Spectrometer (ILAS)-II observations, J. Geophys. Res., 111, D11S12, doi:10.1029/2005JD006260, 2006.

Tilmes, S., Kinnison, D. E., Garcia, R. R., Müller, R., Sassi, F., Marsh, D. R., and Boville, B. A.: Evaluation of heterogeneous processes in the polar lower stratosphere in the Whole Atmosphere Community Climate Model, J. Geophys. Res., 112, D24301, doi:10.1029/2006JD008334, 2007. von Clarmann, T., Glatthor, N., Ruhnke, R., Stiller, G. P., Kirner, O., Reddmann, T., Höpfner, M., Kellmann, S., Kouker, W., Linden, A., and Funke, B.: $\mathrm{HOCl}$ chemistry in the Antarctic Stratospheric Vortex 2002, as observed with the Michelson Interferometer for Passive Atmospheric Sounding (MIPAS), Atmos. Chem. Phys., 9, 1817-1829, doi:10.5194/acp-9-1817-2009, 2009.

von Hobe, M., Ulanovsky, A., Volk, C. M., Grooß, J.-U., Tilmes, S., Konopka, P., Günther, G., Werner, A., Spelten, N., Shur, G., Yushkov, V., Ravegnani, F., Schiller, C., Müller, R., and Stroh F.: Severe ozone depletion in the cold Arctic winter 2004-05, Geophys. Res. Lett., 33, L17815, doi:10.1029/2006GL026945, 2006.

von Hobe, M., Stroh, F., Beckers, H., Benter, T., and Willner, H.: The UV/Vis absorption spectrum of matrix-isolated dichlorine peroxide, $\mathrm{ClOOCl}$, Phys. Chem. Chem. Phys., 11, 1571-1580, doi:10.1039/B814373K, 2009.

von Savigny, C., Rozanov, A., Bovensmann, H., Eichmann, K.-U., Noël, S., Rozanov, V., Sinnhuber, B.-M., Weber, M., Burrows, J. P., and Kaiser, J. W.: The ozone hole breakup in September 2002 as seen by SCIAMACHY on ENVISAT, J. Atmos. Sci., 62, 721-734, 2005a.

von Savigny, C., Ulasi, E. P., Eichmann, K.-U., Bovensmann, H., and Burrows, J. P.: Detection and mapping of polar stratospheric clouds using limb scattering observations, Atmos. Chem. Phys., 5, 3071-3079, doi:10.5194/acp-5-3071-2005, 2005b.

Varotsos, C.: The southern hemisphere ozone hole split in 2002, Environ. Sci. Pollut. Res., 9, 375-376, 2002.

Weber, M., Dhomse, S., Wittrock, F., Richter, A., Sinnhuber, B.M., and Burrows, J. P.: Dynamical control of NH and SH winter/spring total ozone from GOME observations in 1995-2002, Geophys. Res. Lett., 30, 1583, doi:10.1029/2002GL016799, 2003.

WMO (World Meteorological Organization), Scientific Assessment of Ozone Depletion: 2002, Global Ozone Research and Monitoring Project-Report 47, Geneva, Switzerland, 2003.

WMO (World Meteorological Organization), Scientific Assessment of Ozone Depletion: 2006, Global Ozone Research and Monitoring Project-Report 50, Geneva, Switzerland, 2007.

WMO (World Meteorological Organization), Scientific Assessment of Ozone Depletion: 2010, Global Ozone Research and Monitoring Project-Report 52, Geneva, Switzerland, 2011. 